\title{
Type-Specific Stabilization and Target-Dependent Survival of Regenerating Ganglion Cells in the Retina of Adult Rats
}

\author{
Solon Thanos and Jörg Mey \\ Research Laboratory, Department of Ophthalmology, University of Tübingen, School of Medicine, 72076 Tübingen, \\ Germany
}

Axotomy-induced degradation of retinal ganglion cells (RGC) can be delayed if the destructive features of activated microglial cells are pharmacologically neutralized, and prevented if the axons are permitted to regrow into transplanted autologous peripheral nerve (PN) pieces. This study was undertaken to classify the regenerating rat RGC and to examine target-dependent effects on survival of subsets of neurons.

In analogy to the normal rat retina, we have categorized the retrogradely labeled, regenerating RGC into five classes which are morphologically distinct and reminiscent of normal RGC correlates (types I, II, III, $\delta$-cells, and displaced RGC). Six weeks after transplantation of peripheral nerve to the transected optic nerve, large, type I-like cells (RI) constituted $5.7 \pm 2.0 \%$ of the total population. Smaller, round to oval cells of type RII represented the majority of labeled neurons $(64.5 \pm 6.1 \%)$. Cells of type RIII constituted $4.6 \pm$ $1.7 \%$ of the total population and had very typical, middlesized, polarized perikarya and large dendrites. Less trequent $(<1 \%)$ were R- $\delta$ and displaced RGC.

Transplantation of a PN graft which was not reconnected with a central target (blind-ending group) and monitoring of the extant neurons showed a progressive disappearance of the regenerating RGC, such that 6 months after surgery predominantly few large cells survived. When the retinas were treated with macrophage/microglia-inhibiting factor (MIF), and the regenerating axons were guided into the pretectum, predominantly large RGC of type RI survived. Guidance of the axons into their major natural target, the superior colliculus (SC), resulted in selective survival of many small, RIIlike RGC. Calculation of the dendritic coverage factors for the major types of $R G C$ revealed that dendrites of the most abundant small cells of type RII overlapped uniformly and covered the retinal surface completely, whereas cells of types RI and RIII did not suffice for surface coverage. The results suggest that combined suppression of axotomy-induced microglial activation and guidance of regenerating axons with a PN graft into central targets is a suitable technique to

\footnotetext{
Received Dec. 31, 1993; revised June 14, 1994; accepted July 15, 1994.

We thank M. Wild and C. Riedinger for excellent technical assistance and C. Pavlidis for helpful discussions. Dr. Sigrid Henke-Fahle contributed with linguistic advice. The work was supported by the International Research Institute for Paraplcgia (grant to S.T.).

Correspondence should be addressed to S. Thanos, Research Laboratory Department of Ophthalmology, University of Tübingen, School of Medicine, Schleichstrasse 12, 72076 Tübingen, Germany.
}

Copyright (C) 1995 Society for Neuroscience 0270-6474/95/151057-23\$05.00/0 produce sufficient numbers of regenerating axons which may retrieve some functional properties. Target-specific neuronal contacts are likely involved in morphological stabilization and better survival of regenerating neurons.

[Key words: rat retina, ganglion cells, transplantation, macrophage/microglia-inhibiting factor, fluorescent carbocyanine dyes]

Several studies have documented the intrinsic ability of retinal ganglion cells (RGC) of adult rodents to respond to injury with formation of a growth cone and to elongate within the permissive and supporting environment of a grafted piece of an autologous peripheral nerve (PN) (Aguayo, 1985; So and Aguayo, 1985; Berry et al., 1986; Politis and Spencer, 1986; Vidal-Sanz et al., 1987; Thanos, 1988; Carter et al., 1989; Keirstead et al., 1989; Thanos et al., 1993). The PN pieces subserve at least three relevant functions: (1) They provide a permissive biological substrate for axonal growth (Aguayo, 1985). (2) The Schwann cells within the graft proliferate (Aguayo, 1985) and support axonal elongation and neuronal survival (Villegas-Perez et al., 1988 ) by producing neurotrophic factors (Thanos et al., 1989; Mey and Thanos, 1993). (3) They can be used to guide regenerating axons into selected visual centers like the superior colliculus (SC), in which fibers form well differentiated and functional synaptic contacts (Carter et al., 1989; Keirstead et al., 1989; Vidal-Sanz et al., 1991), or like the pretectum, in which they form synapses with sufficient density and appropriate specificity to restore the interrupted function of the retinopretectal circuitry (Thanos, 1992). In addition to this original transplantation paradigm, support of the injured ganglion cells can be achieved with intravitreally injected neurotrophic factors (Sievers et al., 1987; Carmignoto et al., 1989; Mey and Thanos, 1993). Considerable subsidiary effects have also been observed with intravitreally injected macrophage/microglia-inhibiting factor (MIF), an immunoglobulin G-derived tripeptide (Auriault et al., 1983; Plata-Salaman, 1989), which limits the activities of intraretinal microglia (del Rio Hortega, 1932; Perry and Gordon, 1988; Giulian et al., 1989) and enhances the efficiency of axonal regeneration in vivo and in vitro by delaying the process of neuronal cell degradation (Thanos et al., 1993).

The establishment of a regeneration model where adult axons were capable of restoring visual functions prompted an examination of the cells contributing to axonal growth. Normal rat retinal ganglion cells (RGC) can be categorized into distinct morphological types, which are correlated with certain physiological functions. Fukuda (1977) and Perry (1979) were the first to describe rat RGC types (I, II, III). Since then, this widely 


\section{A}
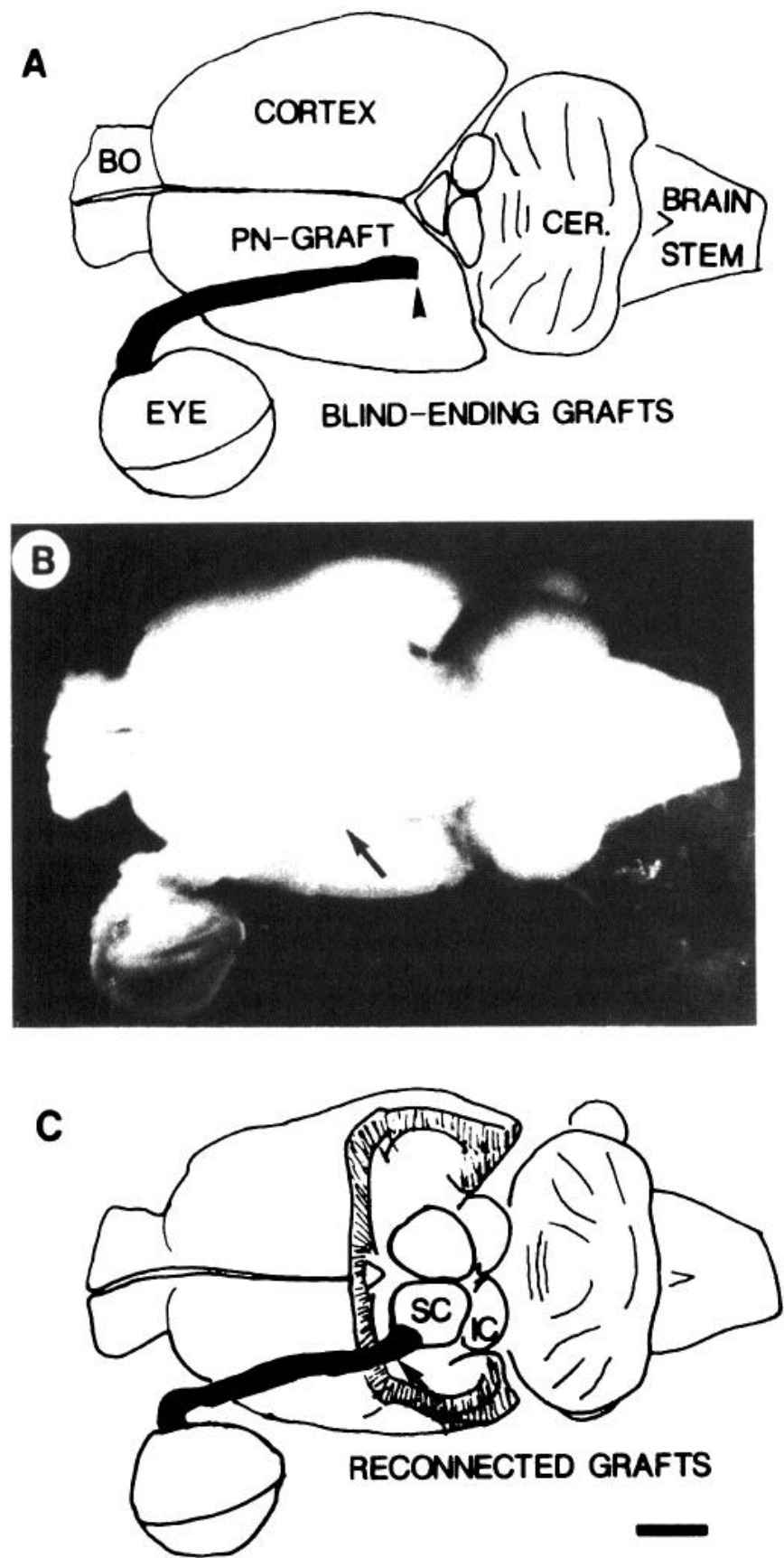

Figure 1. A, Schematic representation of the transplantation used to appose a peripheral nerve graft (PN graft) at the optic nerve stump according to a modification of the technique developed by Vidal-Sanz et al. (1987). Blind-ending graft. The distal end of the graft (arrowhead) was ligated to avoid ingrowth of contaminating fibers from peripheral nerve terminals in the surrounding area. $B$ and $C$, Dorsal view of the in toto prepared rat brain $(B)$ and schematic drawing of the same specimen $(C)$ showing the experimental set-up using PN grafts to connect the retina with the ipsilateral superior colliculus $(S C)$. After the animal's death and perfusion, the occipital cortex was resected to permit visualization of the graft insertion into the SC. Arrow indicates the position where 4Di-10ASP was routinely applied in order to retrogradely fill the ganglion cells whose axons had regenerated into the PN graft. Scale bar, $4 \mathrm{~mm}$.

used basic classification was confirmed by several investigations (Dreher et al., 1985; Sefton and Dreher, 1985; Thanos, 1988a; Peichl, 1989). Dreher et al. (1985) identified two morphological subtypes of class II cells and named them IIA and IIB. Peichl
(1989) subdivided the type I cells into I $\alpha$ and into less frequent I $\delta$ cells and correlated their morphologies with ON and OFF functions. Morphologically, I $\delta$ cells have thinner and more tortuous dendrites than I $\alpha$ cells. In addition to regular RGC classes residing within the ganglion cell layer (GCL), several techniques revealed a population of about $1 \%$ of RGC with their perikarya located within the inner nuclear layer, thus called displaced RGC (Perry, 1979; Thanos, 1988a).

Axotomized and regenerating ganglion cells have been examined morphologically after retrograde labeling with DiI (Thanos, 1988b; Thanos and Aguayo, 1988). Axotomy-resistant RGC had fewer dendritic branches than normal and regenerating correlates (Thanos, 1988b; Thanos and Aguayo, 1988). The present experiments have taken advantage of the combined neuroprotective treatment of axotomized RGC, as described previously (MIF injection and PN transplantation; Thanos et al., 1993). They were designed to address the following issues regarding the population of regenerating ganglion cells: (1) Morphological characterization according to the criteria of normal RGC served to compare the regenerating with normal ganglion cells in the retina, in order to establish whether all types of ganglion cells are represented in the population of regenerating RGC. (2) We examined if the regenerating population of RGC differed morphologically in dependence of the neuroanatomical target of their reconnection, namely the adult SC or the pretectum. These goals were achieved by comparing effects of "blindending" grafts with retinas reconnected with the different targets. (3) To analyze whether the population of regenerating cells may be sufficient to ensure a complete visual field presentation onto the superior colliculus or not, the "dendritic coverage factors" within the retinal inner plexiform layer were determined.

\section{Materials and Methods}

Transplantation at the optic nerve and injection of $M I F$. Adult female rats from the BDE strain (pigmented, weighing 200-230 gm) were used throughout the present study. Operations were performed under intraperitoneal Ketanest/Rompun anesthesia (Ketanest from Parke-Davis, $50 \mathrm{mg} / \mathrm{ml}, 0.2 \mathrm{ml} / 100 \mathrm{gm}$ body weight; Rompun from Bayer, $2 \%$ solution, $0.1 \mathrm{ml} / 100 \mathrm{gm}$ body weight). The left optic nerve was intraorbitally exposed under aseptic conditions and, after longitudinal incision of its meningeal sheath, the nerve was completely transected without affecting the retinal blood supply. Transplantation of the autologous peroneus communis graft was a modification of the original technique (Vidal-Sanz et al., 1987), as follows. After exposure and total transection of the optic nerve, one end of the graft was sutured to the ocular nerve stump. The graft was placed on the dura mater along a predrilled bony groove (about $0.5 \mathrm{~mm}$ in diameter) extending from the orbit roof to the homolateral occipital cortex (Fig. 1).

A total number of 61 rats were used in the present study. In 15 animals the distal end of the graft was not guided into a central target, but was tightened with a nylon 10.0 suture (Ethicon) to prevent exit of the retinal axons and contaminating ingrowth of peripheral neurites into the graft. This set of experiments will be referred to as the "blind-ending" group (Fig. 1A). In 20 animals, the distal end of the graft was inserted into the underlying SC by guiding the graft through a preformed cortical cavity $(2 \times 2 \mathrm{~mm})$. This group will be referred to as the "SC-reconnected" group (Fig. $1 B, C$ ). During the same anesthesia performed for the procedure of grafting, $10 \mu \mathrm{l}$ of anterior chamber fluid was retrieved from the eye with a pulled glass capillary ( $20 \mu \mathrm{m}$ in diameter at the tip) penetrating the cornea. This volume was then replaced by injecting 2.5 $\mu \mathrm{g} / \mathrm{ml}$ MIF (macrophage/microglia-inhibiting factor; Thr-Lys-Pro, Sigma; Auriault et al., 1983; Plata-Salaman, 1989; Thanos et al., 1993) into the vitreous body with a pulled glass capillary penetrating the sclera. Control animals $(n=14)$ received peripheral nerve grafts to reconnect the retina with the SC, but no MIF injection. A further group of 12 animals was used to examine whether targets other than the SC exert different effects on subsets of neurons. To this purpose, we reconnected the axotomized and MIF-treated retina with the pretectum (Thanos, 
1992), the primary visual afferent center that subserves the pupillary constriction reflex and which normally receives about $13 \%$ of the retinofugal axons (Hultborn et al., 1978; Trejo and Cicerone, 1984; Clarke and Ikeda, 1985). This group will be referred to as "PT-reconnected" group throughout this paper. After skin suturing and treatment of the skin wound with antibiotics (gentamicin), the animals were returned to their cages and allowed to survive for various time periods depending on the scope of the experiment. Postoperative care included monitoring of the animals' behavior and wound healing.

The experimental animals were divided into six groups. The first group of 12 animals with reconnected grafts was used for morphometric analysis and classification of the ganglion cells 6 weeks after transplantation. The second group consisted of 15 animals receiving blind-ending grafts with postoperative survival times of $4,6,8,12$, and 24 weeks (three rats at each time point). The third group consisted of 16 animals with SC-reconnected grafts. These animals were analyzed at the same postoperative times as group II animals with blind-ending grafts (three rats for each time). The fourth group of animals comprised six rats having received conditioned PN grafts from sciatic nerves which had been mechanically crushed 1 week prior to grafting in order to enhance the numbers of surviving and regenerating ganglion cells (Bähr et al., 1992). These animals were, except for the transplantation of precrushed PN pieces, treated the same as the first group of animals used for morphometric analysis at the second month after grafting. The fifth group with retinopretectal grafts was allowed to survive for $4,8,12$, and 24 weeks after grafting (three rats each).

Staining techniques. To label RGC whose axons had regenerated into the PN graft, rats were anesthetized again, the transplant was exposed in its epidural segment, transected at a standard distance of $14 \mathrm{~mm}$ behind the eye bulb (Fig. $1 C$ ), and crystals of 4Di-10ASP [N-4-4-(4 didecylaminostyryl)- $N$-methylpropidium iodide, D291 Molecular Probes, Eugene, OR] were deposited at the cross-sectional surface of the nerve (Thanos et al., 1993). The labeled graft stump was then surrounded with resorbable sponge (Gelfoam, Upjohn, Denmark) to prevent displacement of the dye crystal. After suturing of the skin wound the animals were returned to their cages and kept alive for another $4 \mathrm{~d}$ to allow for retrograde transport of the dye and labeling of regenerated ganglion cells.

Fluorescence microscopy and morphometric analysis. After killing the animals with an overdose of chloralhydrate, the transplanted eyes were removed and the retinas dissected and spread on black nitrocellulose filters (Sartorius, Göttingen) with the ganglion cell layer (GCL) upward. The mounted retinas were fixed in $4 \%$ paraformaldehyde in 0.1 m phosphate-buffered saline (PBS) and viewed as whole-mounts through the fluorescein filter of a fluorescence microscope, because 4Di-10ASP has its maximum emission at $563 \mathrm{~nm}$. After removal of the grafted eyes, the animals were intracardially perfused and their brains, including the PN grafts, were dissected for investigation of the anterogradely labeled axon terminals and synapses within the central targets ( $\mathrm{S}$. Thanos and J. Mey, unpublished observations).

To determine RGC densities, the numbers of labeled neurons were counted for each retina in 20 fields of $275 \times 200 \mu \mathrm{m}$, randomly distributed across the entire surface of the whole-mounted organ. The results from the counts were averaged for each retina to calculate the cell density. To verify the reliability of this method, ganglion cell densities were also determined in the same retinas as follows: Four crosswise-oriented sectors of the whole-mount, corresponding to dorsal, ventral, temporal, and nasal retinal quadrants, were photographed with black and white negative films to produce montages from overlapping exposures extending from the optic nerve head to the ora serrata (periphery). Each of the sectors represented $16-18 \%$ of the total retinal surface which had been determined from whole-mount outlines (see Figs. 8-10). In addition to the randomized cell counts, RGC densities were determined from the photomontages. Cell survival results of the experimental procedures were analyzed with the $H$ test after Kruskal and Wallis, whereas the results from different treatments of the RGC were compared by means of the Wilcoxon-Mann-Whitney $U$ test.

Measurements of the cell body sizes were performed by means of a sensitive TV camera (Sony) attached to the fluorescence microscope and connected with an image analysis system (Videoplan, Kontron) equipped for morphometric analysis. Hundreds of cells in each retina and thousands of cells in cach animal group were measured at $400 \times$ magnification to obtain the cell areas calculated automatically from digitizing the perimeter of each cell projected to the screen.

The resolution of the TV camera did not suffice to project and measure the dendritic fields of the labeled ganglion cells, because peripheral
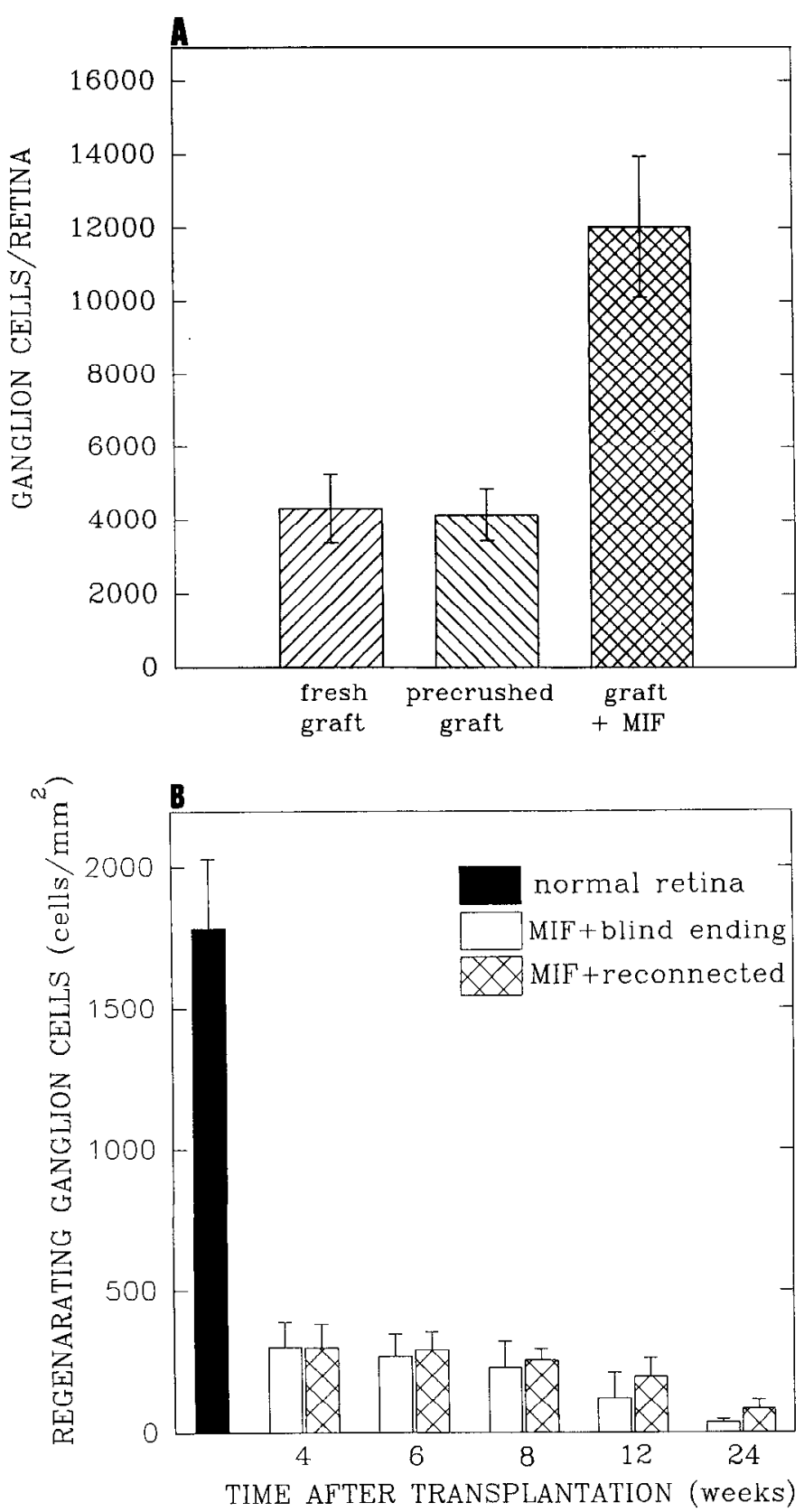

Figure 2. A, Histograms showing the numbers of RGC that contributed to regeneration of axons within the PN graft and were retrogradely labeled with 4Di-10ASP 2 months after grafting according to the three different protocols used in the present study. There was no difference between the populations of labeled RGC in animals which received either "fresh" or "preconditioned" PN grafts. Combined PN grafting and treatment of the retina with intravitreally injected MIF $(2.5 \mathrm{mg} /$ $\mathrm{ml}, 10 \mu \mathrm{l} /$ eye) enhanced the density of regenerating cells to an average of $256 \pm 40 / \mathrm{mm}^{2}$. In accordance, the absolute numbers of cells/retina which were either directly measured over the total surface or calculated from the density (shaded columns) were similar between "fresh" and "preconditioned" grafts, and significantly higher $(P<0.001)$ when MIF was injected in addition to grafting. $B$, Histographic presentation of the course of RGC degeneration determined in the two protocols used to study target-dependent influences. The normal RGC population that could be labeled with 4Di-10ASP from the SC was reduced to less than $20 \%$ after 4 weeks in both groups (MIF + blind-ending grafts and MIF + reconnected grafts). From the sixth week after grafting, reconnected retinas always had more $\mathrm{RGC}$ than retinas with blind-ending grafts. The difference became statistically significant 24 weeks after surgery $(P$ $<0.01$, Student's $t$ test). 
dendritic branches were very thin and could not be resolved. They were therefore photographed on a sensitive black and white negative film (PAN X, 400 ASA) and the dendrites were measured by projecting photographic prints onto the digitizing tablet. Branching frequency of dendrites was defined as the total number of bifurcations per cell and was also determined from photographic prints. Branching frequencies were averaged for each cell category and compared with data obtained from the literature (Thanos, 1988b; Thanos and Aguayo, 1988).

Classification of regenerating ganglion cells. Labeled ganglion cells were grouped into three major categories according to distinctive and consistent morphological criteria in analogy to the morphological classification used in various former reports describing RGC in the normal rctina (Fukuda, 1977; Pcrry, 1979; Thanos, 1988; Pcichl, 1989). Thcsc criteria were: (1) Size and shape of the somata (oval, spherical, polarized, polygonal). (2) Number and orientation of the primary dendrites (a characteristic criterion for grouping cells in the normal retina). (3) Size and morphology of dendrites (area, thickness of branches, branching frequency, stratification of branches, tortuosity of branches). The cells which fulfilled the criteria of being type I-, II-, or III-like cells were called regenerating type I, II, or III (RI, RII, RIII) cells. Large, RI-like cells with tortuous dendrites (Peichl, 1989) have been termed R- $\delta$ cells. Identification of displaced ganglion cells, whose somata were clearly situated deeper than the inner plexiform layer (IPL), was not difficult (Thanos, 1988a).

Since the dendritic territories of most ganglion cells were completely labeled in each retina and the neurons could be grouped into the major three classes, the dendritic coverage factor of cach cell type was detcrmined as RGC density $\times$ diameter of dendritic field (Peichl, 1989). The averaged dendritic field was obtained from the measurements performed for each class of cells and transformed for reasons of simplification into the best fitting circle, as many of them were oval, elliptical, or irregularly shaped. The averaged dendritic "circle" was then superimposed onto every cell belonging to a certain class, in order to study overlap of neighboring cells and to reconstruct the overall pattern of mosaics formed by each major ganglion cell class.

\section{Results}

All animals operated for the different purposes of the study survived the procedure and did not show pathological behavioral alterations. Operated and injected eyes displayed no gross or ophthalmoscopically detectable changes (microphthalmia, infections, or ischemic lesions), such that all of them werc included in the analysis.

\section{Densities of retrogradely labeled ganglion cells}

Deposition of the fluorescent dye 4Di-10ASP into the graft 14 $\mathrm{mm}$ behind the eyecup (Fig. $1 C$ ) sufficed for complete retrograde labeling of ganglion cell bodies and dendrites when the retinas were examined $4 \mathrm{~d}$ later. Labeled ganglion cells were consistently distributed over the whole retinal eccentricity and covered all quadrants, indicating that neurons from the entire retinal surface contributed to regeneration of axons in the PN graft. Cells other than RGC in the GCL and occasionally in the INL remained unlabeled, thus indicating specific label of RGC and no transcellular transport or leakage of the dye. With the method employed, RGC density was slightly higher in the central retinal regions, decreasing toward the peripheral retina. A region of highest cell density corresponding to the area centralis in the temporal retina of normal rats (Schober and Gruschka, 1977) could not be identified in the regenerated retinas, although $4 \mathrm{Di}$ 10ASP labeling does reproduce this feature in the normal retina prior to axotomy-induced degeneration (Mey and Thanos, 1993).

In the original procedure of grafting and labeling regenerating ganglion cells with horseradish peroxidase, an average of 3610 cells could be identified within 20 grafted retinas of Lewis rats (Vidal-Sanz et al., 1987). Deposition of the fluorescent dyes Dil or Fast blue into the PN graft between $15 \mathrm{~d}$ and 3 months after grafting revealed a decreased density of labeled ganglion cells from $194 \pm 25 / \mathrm{mm}^{2}$ at $15 \mathrm{~d}$ to $97.7 \pm 9$ cells $/ \mathrm{mm}^{2}$ at the third month (Villegas-Perez et al., 1988).

The extent of axonal growth has been confirmed in the Sprague-Dawley strain of rats, where grafting of PN segments resulted in regeneration of about $190 \mathrm{RGC} / \mathrm{mm}^{2}$ (Thanos et al., 1993). This number of regenerating $R G C$ is confirmed in the present study. In fresh grafts, the total number of cells was 4270 $\pm 1065 \mathrm{RGC} /$ retina when determined directly from photomontages, and $4346 \pm 810 \mathrm{RGC}$ when calculated from randomized cell density counts (Fig. 2A). Pretreatment of the peripheral nerve 1 week prior to transplantation resulted $(n=6)$ in very similar average numbers of RGC after 2 months (4084 \pm 718 cells/retina; Fig. $2 \mathrm{~A}$ ) and indicated that such conditioning of the grafted pieces was not supportive of enhanced regeneration. A different mode of treatment, however, was significantly effective: intravitreal injections of MIF and simultaneous transplantation of PN grafts (Thanos et al., 1993), doubling the numbers of regenerating RGC (average: $11,380 \pm 1877, n=6$; Fig. $2 A$ ). All data concerning classification, morphometry, and determination of coverage factors in the present paper were therefore obtained from grafted retinas having received injections of MIF during the procedure of axotomy and grafting.

In the paradigm of optic nerve replacement with $\mathrm{PN}$ pieces, Inust of the RGC disappeared through cell death (Vidal-Sanz

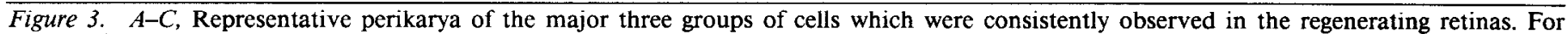

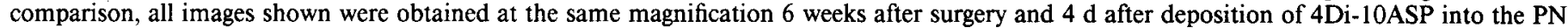

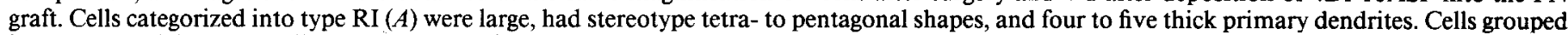

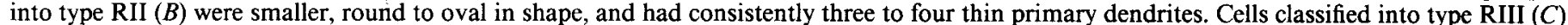

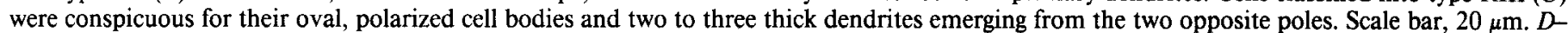

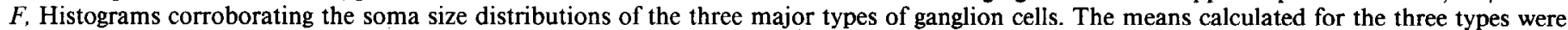

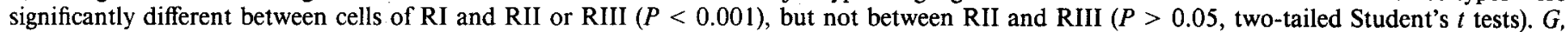

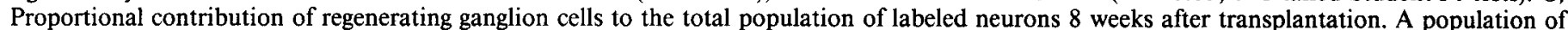



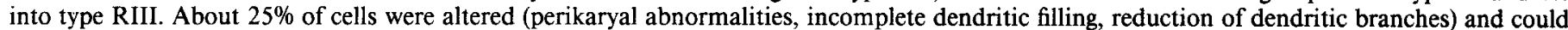

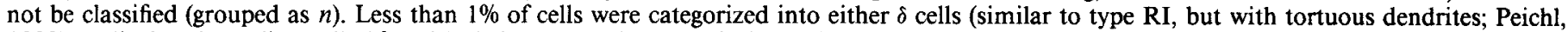
1989 ) or displaced ganglion cells ( $d p$, with their somata situated within the inner nuclear layer).

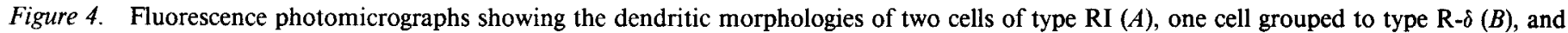


branching, and morphology. Scale bar, $50 \mu \mathrm{m}$.

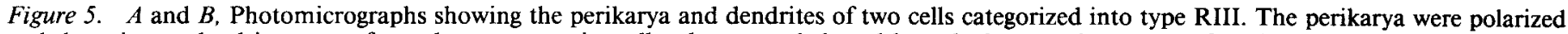

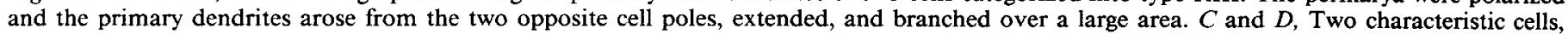
which were grouped as "nonclassifiable" because of the reduced dendritic arbors and the altered morphologies. Scale bar, $50 \mu \mathrm{m}$. 

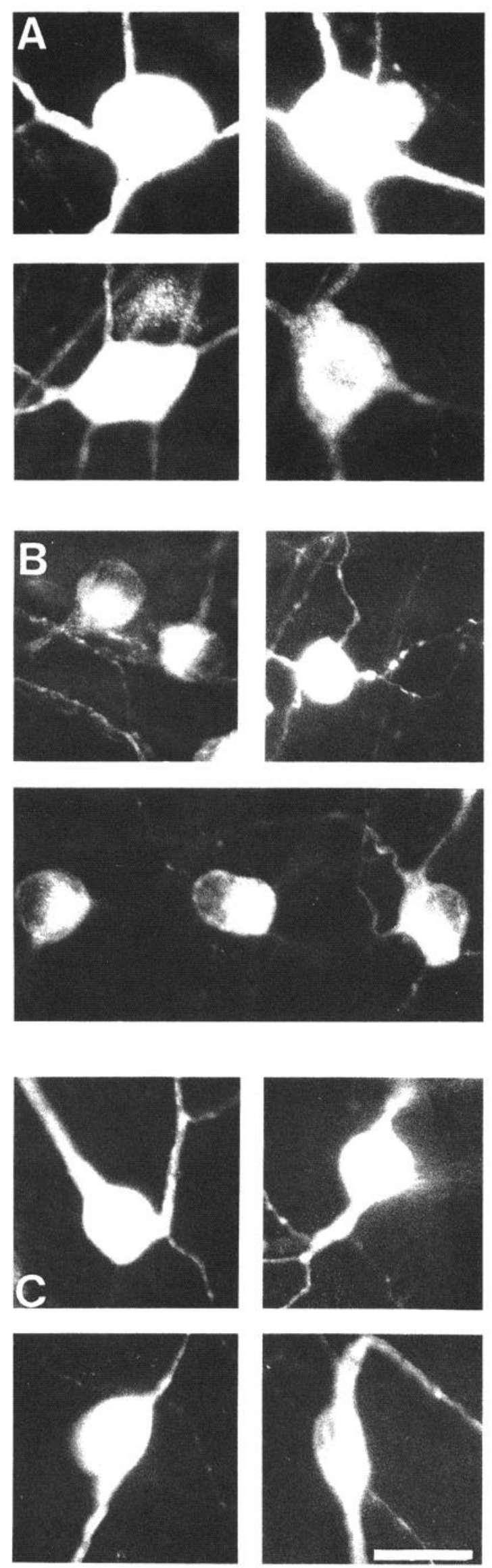
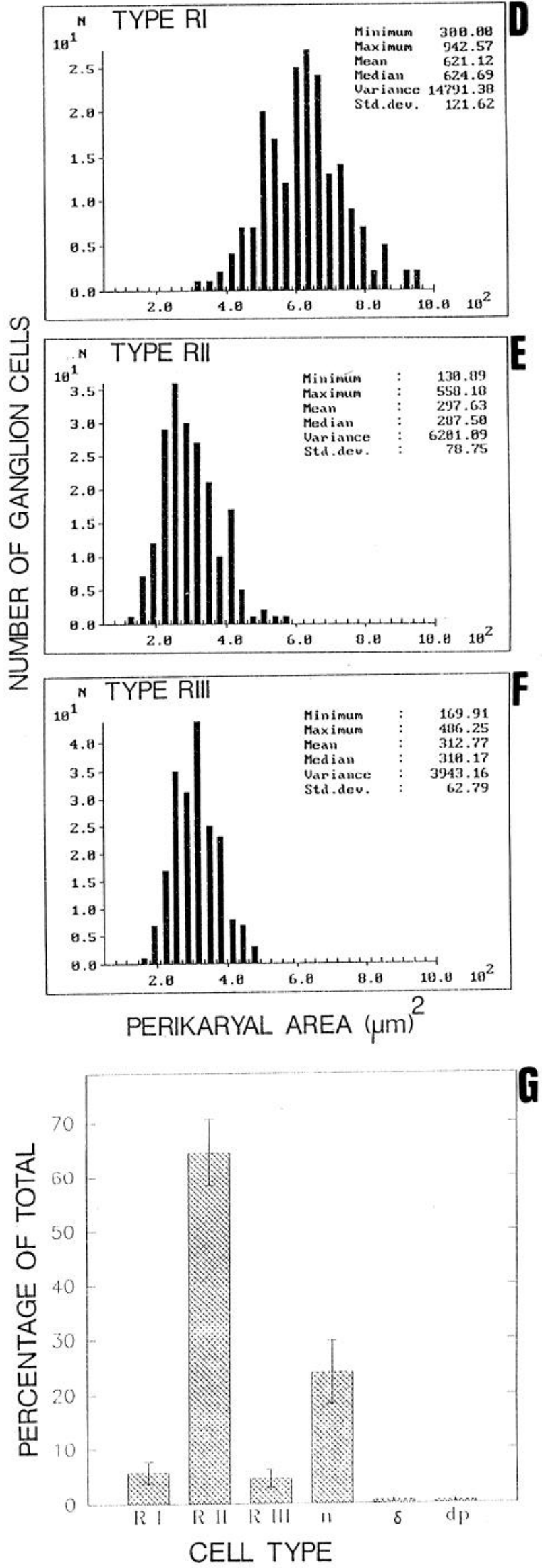

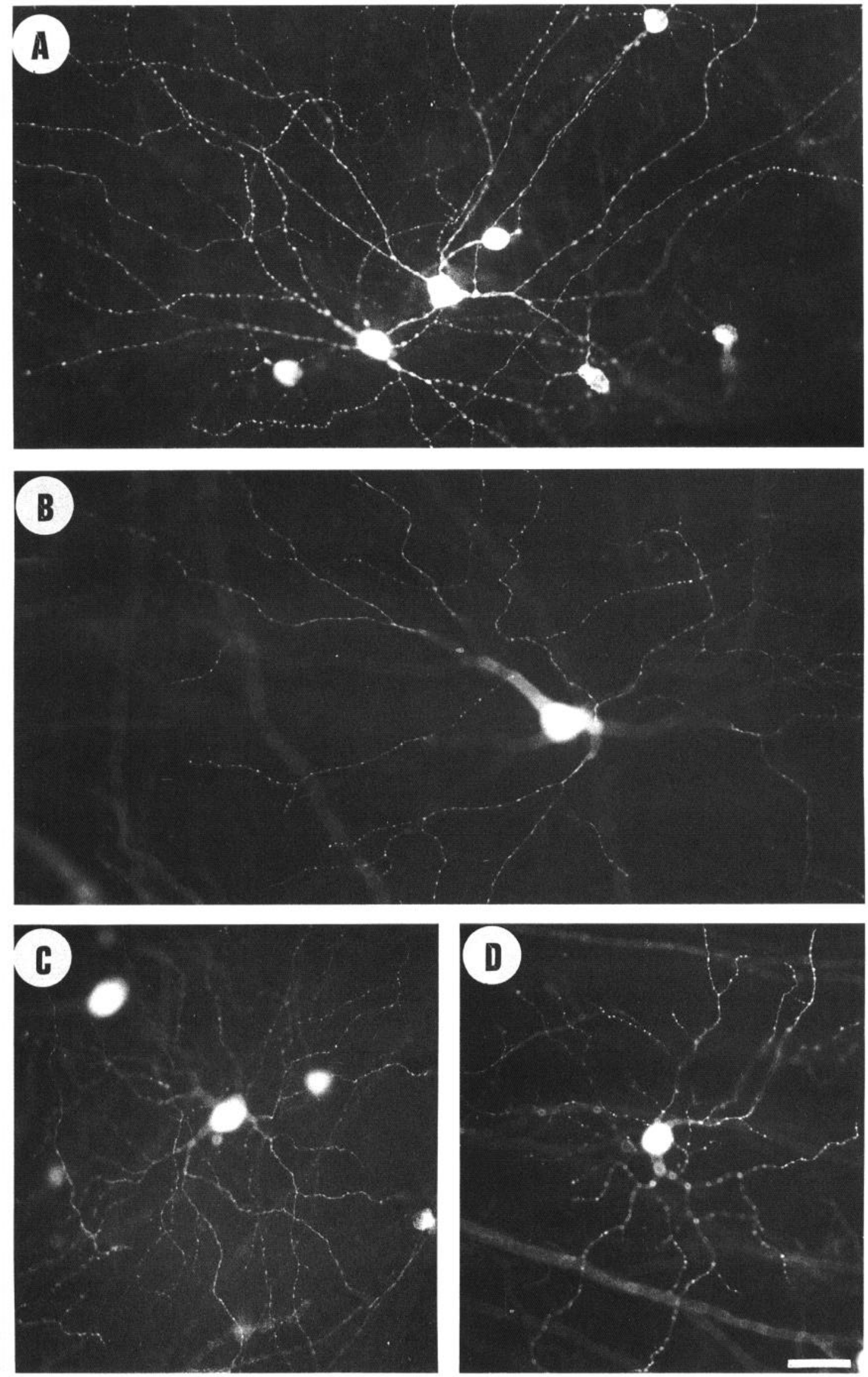

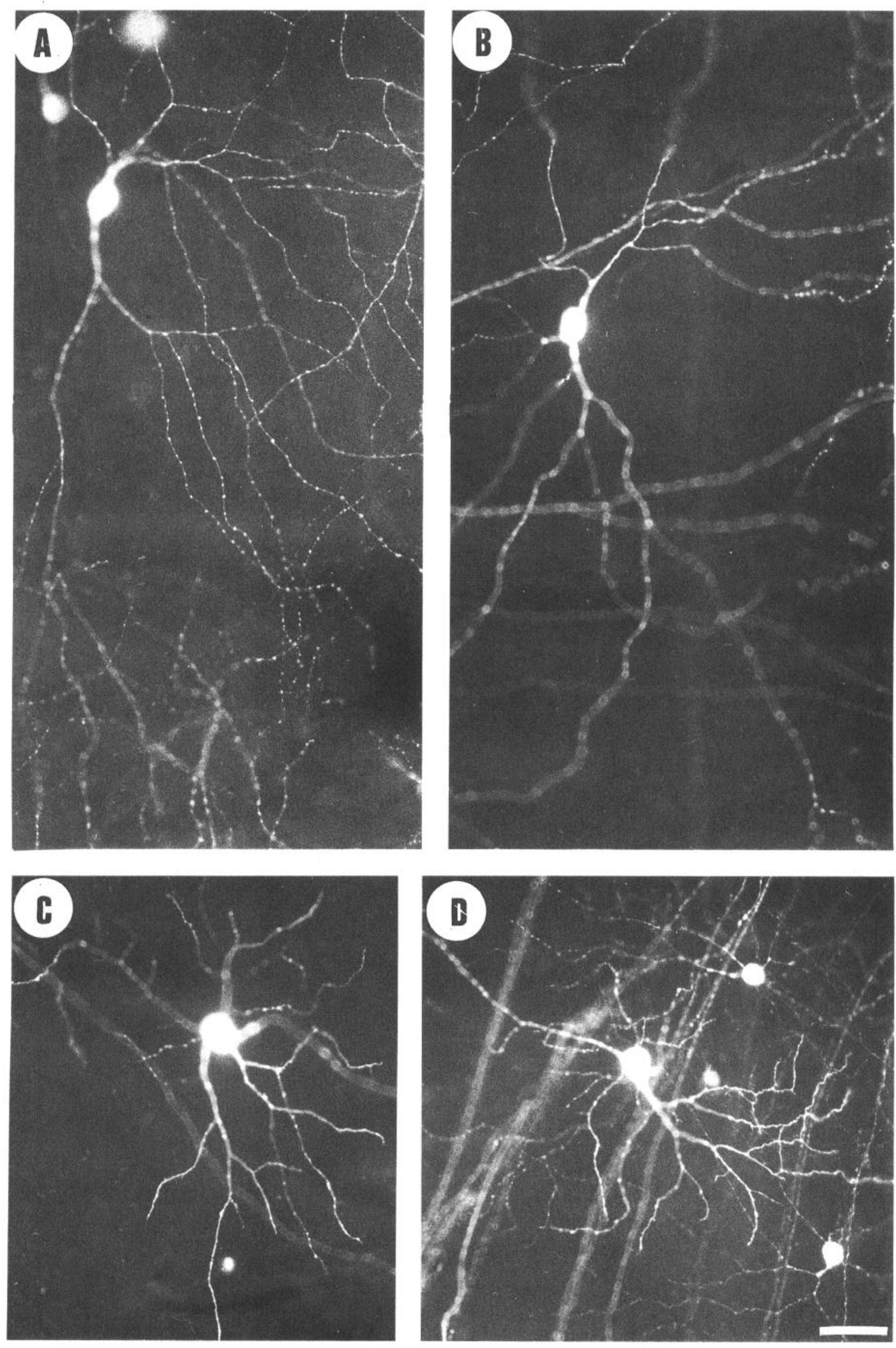


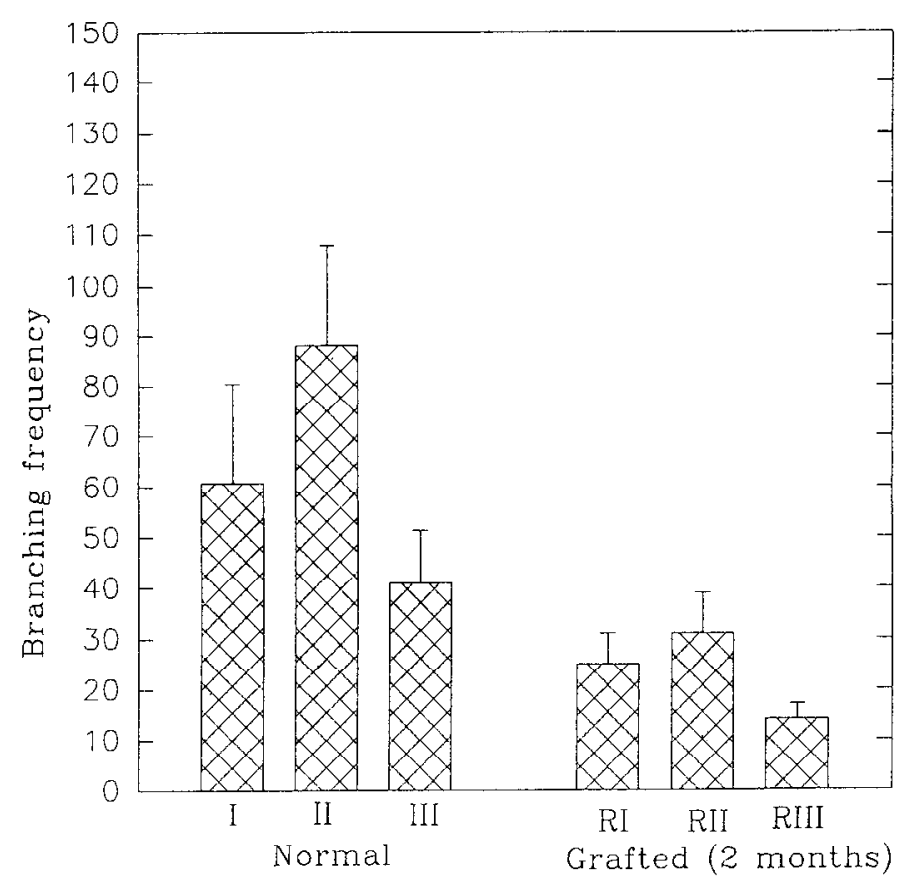

Figure 6. Graph showing the frequency of branching among the three major types of regenerating ganglion cells. The numbers of bifurcations were determined in 30 cells of each type and are presented as means \pm $\mathrm{SD}$ in the diagram. For comparison, the branching frequencies of normal ganglion cells are shown (30 cells per type). There is a significant reduction of branches $\left(P<0.01 ; \chi^{2}\right.$ test comparing the means of the paired populations).

et al., 1987; Villegas-Perez et al., 1988; Thanos et al., 1993). Out of $1780 \pm 240 \mathrm{RGC} / \mathrm{mm}^{2}$ which could be retrogradely filled with 4Di-10ASP from the SC, about $300 \mathrm{RGC} / \mathrm{mm}^{2}$ had their axons regrown and could therefore be labeled from the PN graft at the end of the first month after grafting and injection of MIF (Fig. $2 B$ ). The numbers of regenerating RGC decreased steadily between the sixth week and the sixth month after surgery (Fig. $2 B$ ). This decrease tended to occur faster in retinas with blindending rather than with SC-reconnected grafts, and became statistically significant at the sixth month atter surgery (Fig. $2 B$ ).

\section{Morphometry and classification of regenerating ganglion cells}

The consistent staining of morphologically identifiable regenerating RGC permitted us to categorize their somata into cell groups with similar characteristics. We selected the sixth week (right after onset of reinnervation) and the 24 th week (long-term innervation) after grafting as fixed time points to morphometrically analyze the regenerating populations of RGC and to perform a classification. Type RI cells (Fig. $3 A$ ) were distributed throughout the retinal surface, comprised a population of about $5 \%$ of the total RGC (Fig. $3 G$ ), and were unequivocally identifiable neurons because of large $\left(621 \pm 122 \mu \mathrm{m}^{2}\right)$ tetra- to pentagonal somata (Figs. $3 A, 4 A$ ). The primary dendrites were thick and arose stereotypically from one of the corners of the polygonal perikarya (Fig. 3A). Type RII cells with small (298 $\pm 7 \mathrm{l} \mu \mathrm{m}^{2}$ ) oval to spherical perikarya (Figs. $3 B, 4 B$ ) comprised the majority of regenerating $\mathrm{RGC}(65 \%$ of total; Fig. $3 G)$ and were characterized by three or four thin primary dendrites (Fig. $3 B$ ). The perikarya of type RIII cells (Fig. $3 C$ ) were most typical, as they were oval to bipolar and of middle sizes $\left(313 \pm 63 \mu \mathrm{m}^{2}\right.$; Fig. $4 B$ ). These cells amounted to $4 \%$ of the total population
(Fig. 3G) and extended two or three thick primary dendrites emerging from the two poles of the cell (Fig. 3C). A fourth group of cells, which included about $25 \%$ of the total population (Fig. $3 G$ ), were ganglion cells with dramatically altered morphologies when compared to normal types of RGC. They were therefore grouped as unclassifiable RGC. A displaced position of the cell body at the vitreal aspect of the INL served as criterion to identify the typical, small group of displaced ganglion cells, which contained less than $1 \%$ of the regenerating neurons.

The dendritic morphologies and sizes of the regenerating ganglion cells were the second criterion to be analyzed for including a cell into one of the groups of RGC classification. It was possible to correlate large, stereotype patterns of elaborate, straight dendritic arborization with cell bodies of RI type (Fig. $4 A$ ). The high staining resolution achieved with $4 \mathrm{Di}-10 \mathrm{ASP}$ allowed us to discriminate the incidence of so-called $\mathrm{R}-\delta$ cells, which fulfill all somal criteria for RI cells but show a bistratified ramification with more tortuous, thinner branches (Fig. $4 B$ ). The dendrites belonging to the more numerous type RII somata were also typical, but displayed a higher variation in morphology, size, and mode of stratification. They had thin dendrites with slightly diffuse stratification (Fig. $4 C, D$ ). The morphological patterns of type RIII dendrites (Fig. $5 A, B$ ) were also type specific and reminiscent of normal type III RGC (Thanos, 1988a). Two to three thick primary dendrites gave rise to larger, sometimes diffusely branching dendritic fields (Fig. $5 A, B$ ). The large population of unclassifiable RGC was scattered throughout the retina surface. They had small to middle-sized perikarya and dendrites with highly reduced numbers of dendritic branches (Fig. $5 C, D$ ), probably due to retraction of some branches (Thanos and Aguayo, 1988). The frequencies of dendritic branching varied between the three regular cell groups (RI, RII, and RIII), although they were not significantly different $\left(P<0.05, \chi^{2}\right.$ test) when comparing the three major regenerating groups of cells (Fig. 6). The branching frequencies were significantly decreased $(P<0.01)$ when regenerating and normal correlates of $\mathrm{RGC}$ were com pared (Fig. 7) after labeling with the same technique, by applying the dye either into the optic nerve or into the SC.

Target-dependent appearance of regenerating ganglion cells in $S C$-connected retinas

The perikaryal areas of regenerating populations of RGC.were compared with those of normal RGC. To perform analyses at comparable times of retrograde transport and intensity of labeling, 4Di-10ASP was always placed at the same standardized distance from the eyecup that corresponded to the distance between retina and SC (ca. $14 \mathrm{~mm}$ ), and the retinas were examined $4 \mathrm{~d}$ later. Normal retinal ganglion cells were labeled from the $\mathrm{SC}$ and used $4 \mathrm{~d}$ later as controls.

The averaged sizes of axotomized and regenerating cells increased significantly 4 weeks after grafting (Fig. 7) when compared to normal correlates. This was due to the chromatolysis and cell swelling caused by axotomy of the neurons (Liebermann, 1970). In the experimental paradigm that is based on grafting a PN at the optic nerve stump, first axons start to regrow by the sixth day after grafting (Trecarten et al., 1987; VidalSanz et al., 1987) and the axons advance by a speed of about $1.33 \mathrm{~mm} /$ day to bridge the distance between retina and central targets within 4-5 weeks (Thanos, 1992). In blind-ending grafts with the distal end of the PN lying on top of the meninges (see Fig. 1A), uniformly distributed RGC were observed between the fourth week and the sixth month after grafting. Densely 

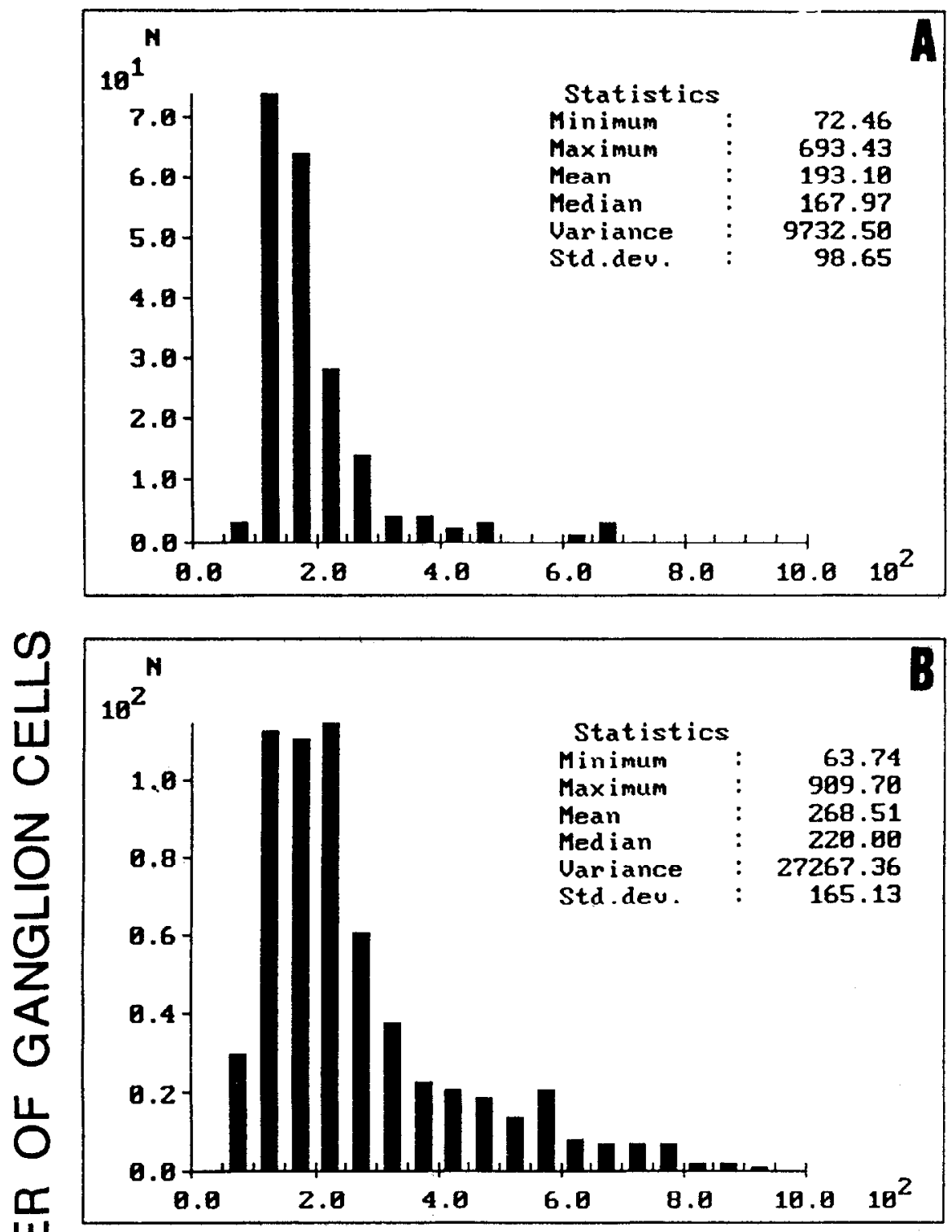

$\sum_{z}^{\infty}$

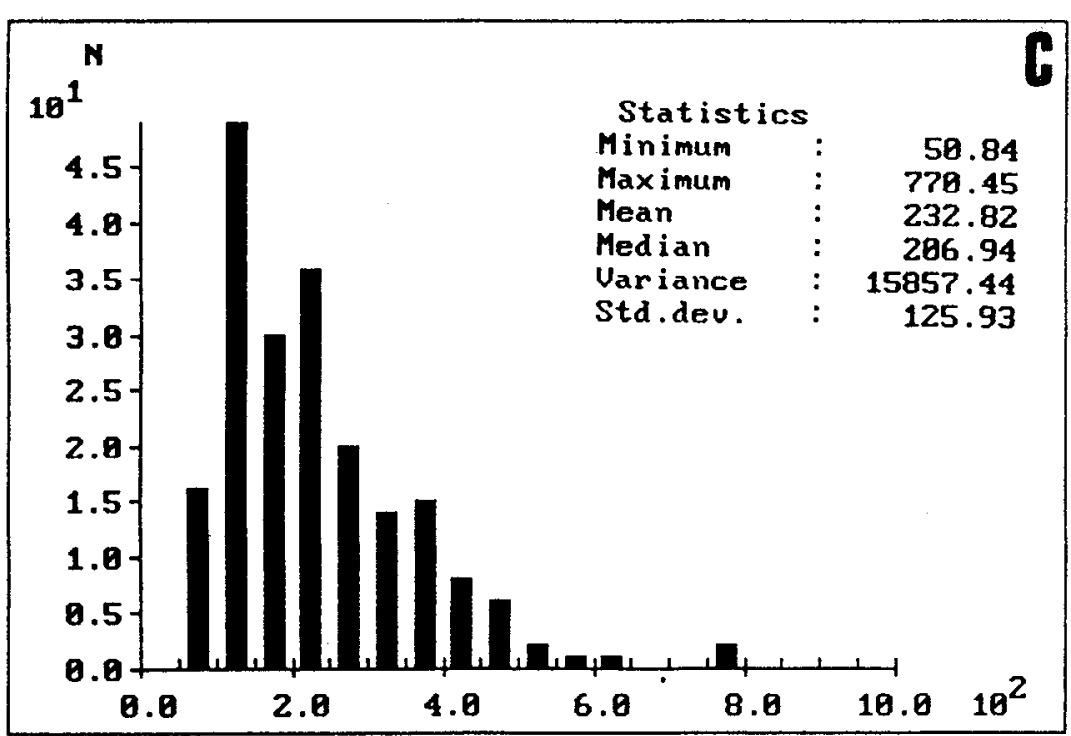

PERIKARYAL AREA $\left(\mu \mathrm{m}^{2}\right)$

Figure 7. Histograms comparing the perikaryal areas of normal RGC $(A)$, blind-ending $\mathrm{RGC}(B, 4$ weeks after grafting), and RGC reconnected with the $\mathrm{SC}(C, 4$ weeks after grafting). There was an apparent chromatolysis-dependent increase in the soma size in both experimental groups $(P<0.05$ between $A$ and $B$ or $C$ ). However, there was no significant difference between blindending and SC-reconnected RGC at this stage of regeneration $(P>0.05)$. 

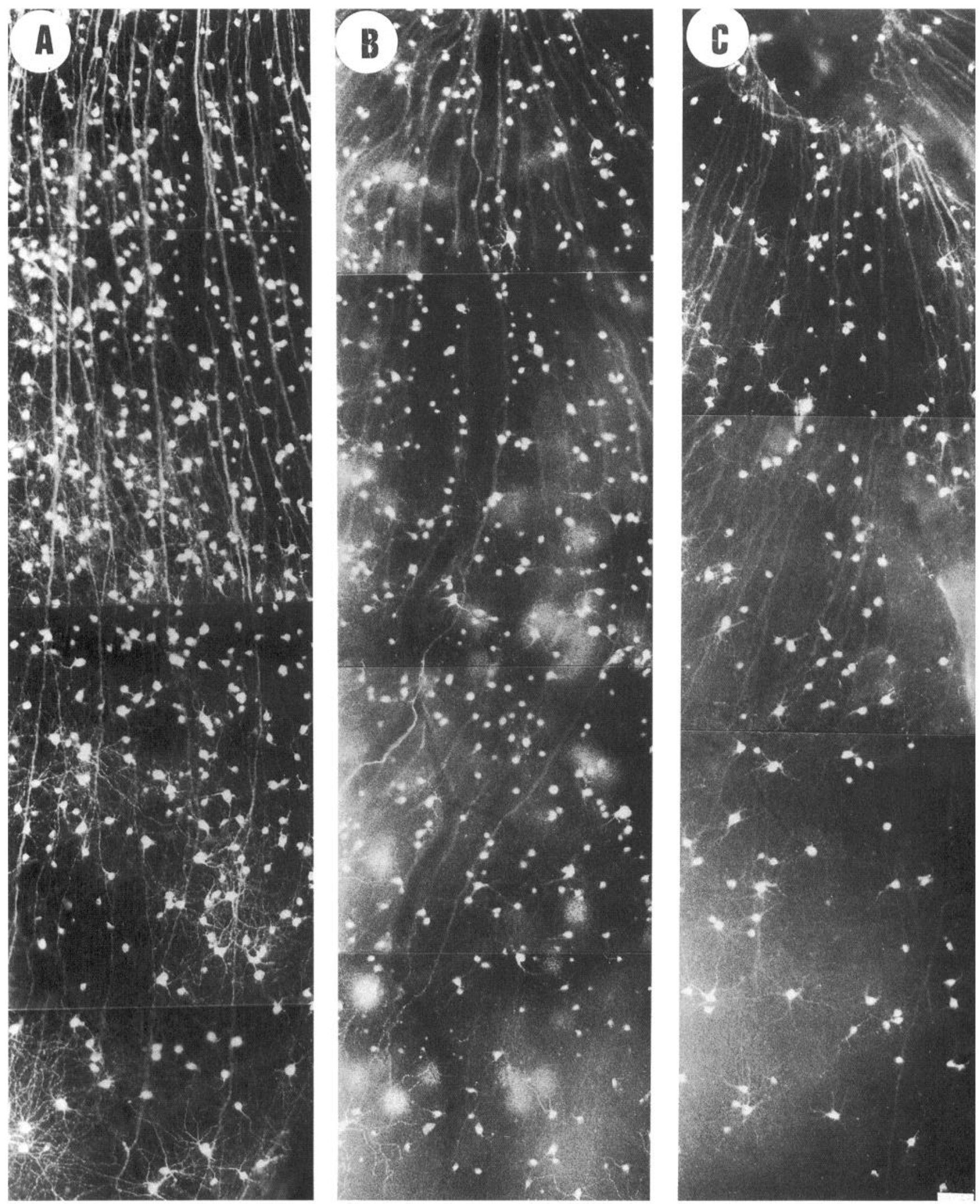

Figure 8. Fluorescence photomontages showing retinal sectors with regenerating ganglion cells in the blind-ending grafts at $4(A), 6(B)$, and $8(C)$ weeks after grafting and $4 \mathrm{~d}$ after deposition of $4 \mathrm{Di}-10 \mathrm{ASP}$ into the graft. The sectors represent the surface between the optic nerve head (top) and the retinal periphery (bottom). The same radial orientation (temporal to optic nerve head) has been photographed in all retinas in order to allow for direct comparison between the retinas operated according to different protocols. There was a steady reduction in the densities of labeled cells from the fourth $(A)$ to the sixth $(B)$ and eighth $(C)$ weeks after transplantation (see also Fig. $2 B$ for quantification). In addition, there was always a slight gradient of ganglion cell density, which decreased with eccentricity (from top to bottom in each montage). Scale bar, $100 \mu \mathrm{m}$. 
labeled cell bodies of various sizes and with elaborate dendritic fields were found across the entire retinal surface at 4,6 , and 8 weeks after grafting (Fig. 8). Regarding the cell numbers, there was a steady decrease in the densities of labeled RGC between the fourth and the eighth week (see Fig. $2 B$ for quantification), with dcpletion affecting similarly all quadrants and all eccentricities across the retinal surface. Figure 8 shows the typical RGC distribution patterns along the central-peripheral radius of the temporal retina at the fourth to eighth weeks after transplantation.

Very similar morphologies and distribution patterns were displayed by regenerating cells in retinas whose axons were reconnected with the SC by means of the PN graft (see Fig. $1 B, C$ ) and examined at the fourth week after transplantation (Fig. $9 A$ ). This pattern was indistinguishable from that displayed by RGC with blind-ending grafts (compare Figs. 8A, 9A). At 6 weeks after grafting - that is, about 2 weeks after axons had been expected to penetrate the $\mathrm{SC}$-the densities of labeled RGC were higher than in retinas with blind-ending grafts (Fig. 9B). The difference between "blind-ending" and "reconnected" experiments became more pronounced when the retinas were examined 8 weeks after grafting (Fig. 9C); that is, 4 weeks after the axons had arrived at the $\mathrm{SC}$ parenchyma. There was a tendential, but statistically not significant, difference between reconnected and blind-ending RGC (see Fig. $2 B$ for quantification), presumably indicating the disappearance of RGC that failed to produce synapses in the brain.

Further reduction of the ganglion cell numbers was examined in both groups of transplants by measuring the RGC densities 12 weeks after grafting (Fig. 10). Predominantly large and, compared to earlier stages of regeneration, fewer RGC (see Fig. $2 B$ ) with uniform distribution across the retina were observed in retinas obtained from blind-ending grafts (Fig. 10A). At the same time after grafting, both large and smaller RGC were found within retinas with reconnected grafts (Fig. 10B,C). The numbers of ganglion cells also differed between the two groups, being higher in all animals whose ganglion cell axons had been guided into the SC (see Fig. 2B).

The size distributions of RGC within the two groups of experimental animals were compared to normal RGC of all three classes, whose perikaryal areas ranged from 72 to $693 \mu \mathrm{m}^{2}$ (mean: $193 \pm 99 \mu \mathrm{m}^{2}$; see Fig. 7A). As shown for the fourth week after grafting (see Fig. $7 B, C$ ), regenerating $\mathrm{RGC}$ were larger also at later stages. However, between the sixth and the 24th weeks, a shift in the distribution of perikaryal sizes was observed when comparing the two groups of animals. The average perikaryal sizes of blind-ending RGC were $335 \pm 166 \mu \mathrm{m}^{2}$ at the sixth, $351 \pm 132 \mu \mathrm{m}^{2}$ at the eighth, and $302 \pm 88 \mu \mathrm{m}^{2}$ at the 12 th week after grafting. At the same time of examination, reconnected ganglion cell sizes were $305 \pm 155 \mu \mathrm{m}^{2}, 322 \pm 122 \mu \mathrm{m}^{2}$, and $249 \pm 90 \mu \mathrm{m}^{2}$ (Fig. 11). The differences between the groups were significant at all times of comparison (Mann-Whitney $U$ test, $p<0.01)$.

Twenty-four weeks after grafting (three retinas per group), $R G C$ with large perikarya predominated in all retinas from blind-ending grafts (Fig. 12A). The density of labeled RGC dropped to $35 \pm 12$ cells per $\mathrm{mm}^{2}$ (see Fig. $2 B$ ), indicating that some of the regenerating ganglion cells had disappeared. In reconnected grafts, the density of RGC was significantly higher $\left(82 \pm 34\right.$ cells $/ \mathrm{mm}^{2}$; see Fig. $\left.2 B\right)$. The population of cell bodies included both large RGC and small cells reminiscent of type RII (Fig. 12B). Measurements of the perikaryal sizes in both groups revealed that reconnected retinas had on average significantly smaller perikaryal areas than retinas from blind-ending grafts (Fig. 12C,D).

Blind-ending RGC were large and, although reminiscent of either type RI or RIII, unclassifiable at the 24th week after grafting, because most of them were morphologically altered and had dendrites with very reduced branching patterns (Fig. $12 A$ ). Classification of RGC was possible in SC-reconnected retinas at the 24th week after grafting by applying the same morphological criteria as described above, and revealed that all major types of cells were well discernible (Fig. 13). Type RI cells, comprising about $30 \%$ of the labeled neurons, were uniformly distributed throughout the retinal surface and easy to identify because of their large cell bodies and dendrites (Fig. $13 A, F)$. Type RII cells had typical small cell bodies and bushy, thin dendrites (Fig. 13B,C). They represented about $40 \%$ of the labeled RGC (Fig. 13F), whereas type RIII cells amounted to about $10 \%$ of the total population (Fig. 13F), displaying their typical polarized cell bodies with large, rarely branching dendrites (Fig. 13D). A large number of about $20 \%$ of RGC were unclassifiable at the 24th week after grafting (Fig. 13E). In addition, a few displaced RGC (less than 0.3\%) were also observed 24 weeks after surgery.

\section{Target-dependent appearance of regenerating ganglion cells in $P T$-reconnected retinas}

A small subpopulation of about $13 \%$ of the retinofugal axons, which belong to large type I cells, terminates within the pretectum, and in particular within the nucleus olivaris pretectalis (Hultborn et al., 1978; Trejo and Cicerone, 1984), which subserves the light-induced constriction of the pupil as response to illumination. In a previous investigation (Thanos, 1992), guidance of the retinal contingent of regenerating axons into this area was used to restore the interrupted circuitry of the pupillary reflex in adult rats and documented that the formation of functional synapses is, in principle, possible. In the present study we have used rats with retinopretectal reconnections (Fig. 14A) to study whether this area, which predominantly receives retinal input from large RGC, has different survival effects as compared to the colliculus, the latter supporting the survival of small RGC. Since axons first arrive at the distal end of the graft at about 4 5 weeks after surgery (Thanos, 1992), the initial populations of regenerating neurons, analyzed after 4 weeks (Fig. 14B), were indistinguishable from those in the two other groups. Ingrowth of retinal axons into the pretectum at around the fifth week and examination of the retrogradely filled RGC at 6 and 12 weeks after surgery resulted in retention of more RGC than in the blind-ending group, but fewer RGC than in the retinocollicular group at corresponding stages after grafting (compare Figs. $3 G$, $14 B$ ). Classification of $\mathrm{RGC}$ showed similar proportional contribution of identifiable cell types with retinocollicular transplants 6 wecks after grafting (Fig. $14 C$ ). However, a marked shifting to large, type RI cells was noted 12 weeks after grafting (Fig. 14C). At this stage, type RI cells represented about $40 \%$, type RII cells about $25 \%$, and type RIII cells $8 \%$ of the total population, which also contained unclassifiable cells as well as a few displaced RGC and $\delta$-like cells (Fig. 14C). The morphologies of neurons reconnected with the pretectum (Fig. 15A) were initially identical to those of the other two groups. However, when 12 weeks had elapsed from grafting, large cells formed the predominant subpopulation of retrogradely filled neurons (Fig. $15 B, C$ ) with a uniform distribution across the retinal sur- 

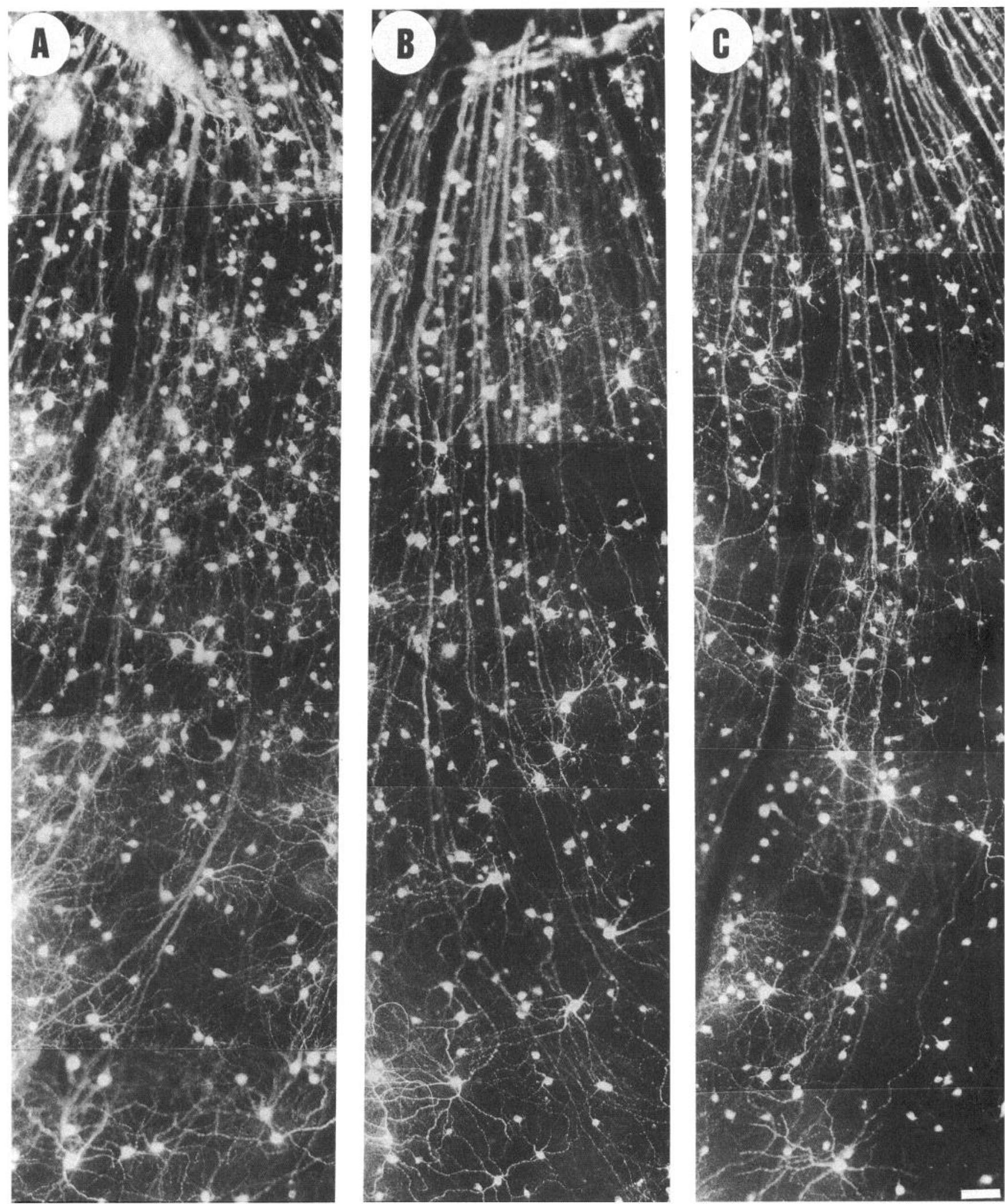

Figure 9. Photomontages showing similar sectors as in Figure 8 of transplanted and SC-reconnected retinas at $4(A), 6(B)$, and $8(C)$ weeks after grafting. At the fourth week the image was morphologically and quantitatively similar to that of blind-ending grafts at corresponding time after surgery (see Figs. $2 B, 8 A$,). A morphological and quantitative difference became just detectable at the sixth week and was more pronounced 8 weeks after grafting. Comparison of the cell densities and of ganglion cell morphologies in Figures $8 C$ and $9 C$ revealed more cells and more elaborate dendrites in Figure $9 C$, which shows the same retinal sector as in Figure $8 C$, but after reconnection with the SC. Scale bar, $100 \mu \mathrm{m}$. 



Figure 10. Direct comparison of temporal retinal sectors from one blind-ending $(A)$ and two SC-reconnected $(B, C)$ retinas 12 weeks after transplantation. $A$, Predominantly large ganglion cells have been labeled from blind-ending grafts. The density of cells was reduced when the retinas were compared with those at earlier stages of regeneration (compare with Fig. 8). $B$ and $C$, These SC-reconnected retinas had predominantly smaller cells than blind-ending retinas and always higher densities of regenerating neurons. Scale bar, $100 \mu \mathrm{m}$. 

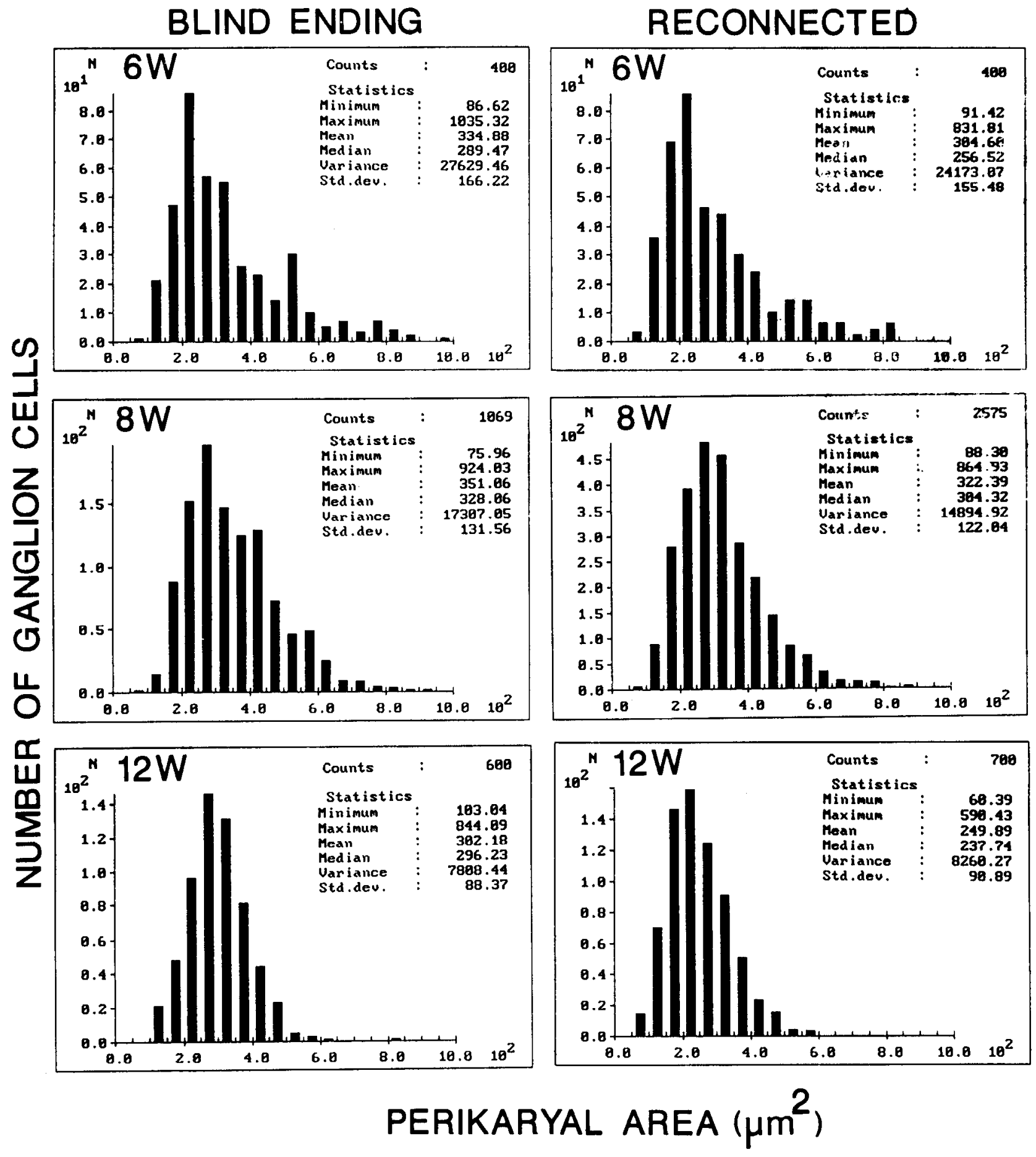

Figure 11. Histograms showing the perikaryal area distribution in blind-ending and SC-reconnected grafts between 6 and 12 weeks after grafting. Cells were measured from three retinas at each time point. Equal numbers of cells randomly distributed with respect to eccentricity and quadrant were pooled from the three retinas to obtain the total numbers of cells shown in the histograms. There was no significant difference between the two groups of cells at $6(P>0.05)$ and $8(P>0.05)$ weeks (Mann-Whitney $U$ test), although reconnected cells were slightly smaller. At 12 weeks, blind-ending cells had significantly larger cell bodies than reconnected cells $(P<0.01)$.

face. Examination of these cells at higher microscope magnifications permitted to categorize them into the various types, and to establish that about $40 \%$ of them (Fig. 14C) had type RIlike, large, polygonal perikarya and large dendrites (Fig. 15C). Examination of the three PT-reconnected retinas at 24 weeks after grafting revealed no morphological difference from the cells examined at 12 weeks after grafting. However, there was a further, not significant, proportional shifting toward larger cells
(48\% RI, $20 \%$ RII, $8 \%$ RIII, and $24 \%$ unclassifiable; a total of 1450 completely labeled cells retrogradely labeled and classified).

\section{Dendritic coverage of regenerating $R G C$ within the retina}

As this may be a prerequisite for functional relevance, we asked whether the population of regenerating RGC sufficed to cover the retinal surface with their dendrites. The dendritic territories 

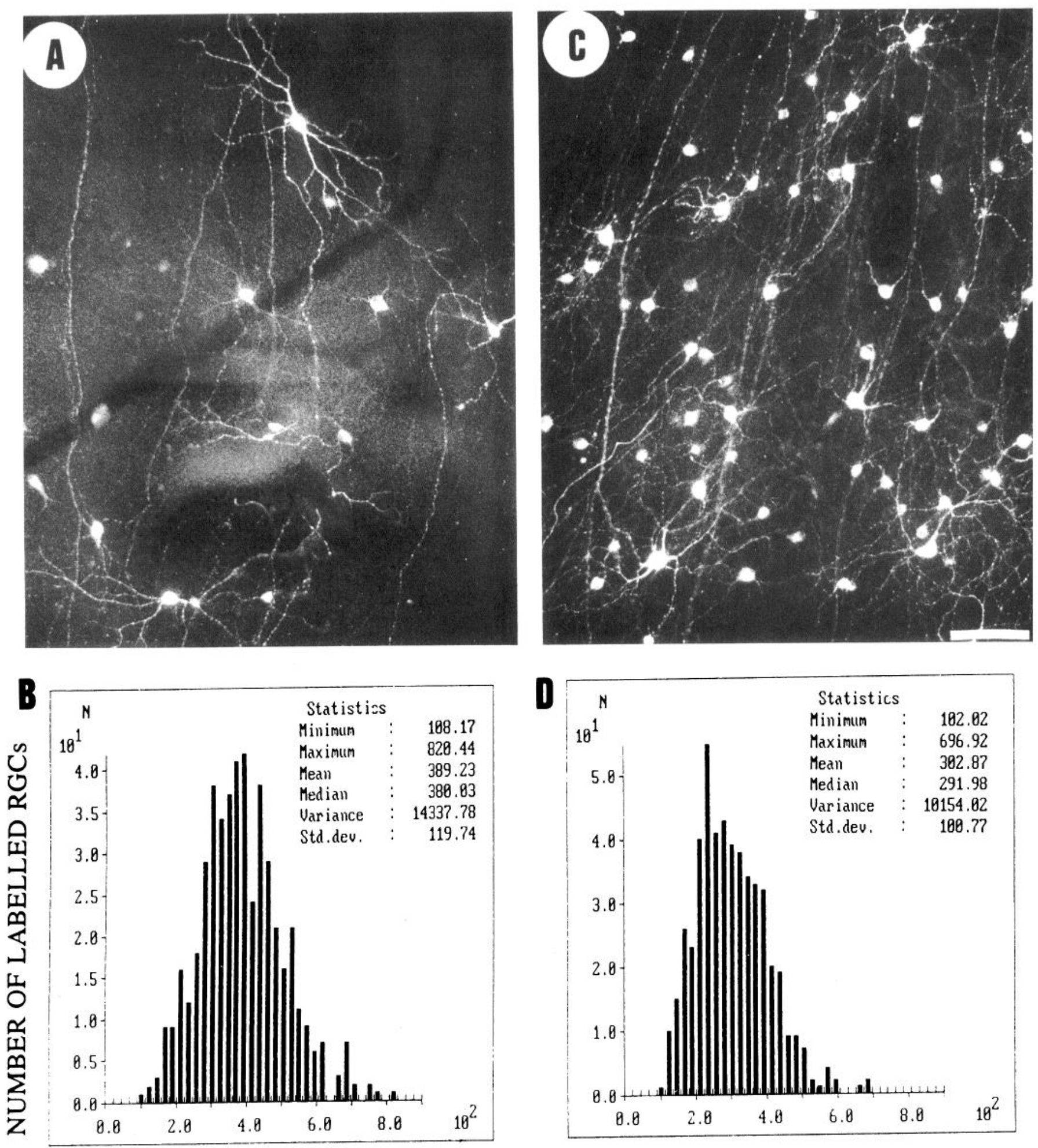

\section{PERIKARYAL AREA [ $\left[\mu^{2}\right]$}

Figure 12. $A$ and $B$, Typical morphological images and soma size distributions in retinas with blind-ending grafts 6 months after surgery and 4 $\mathrm{d}$ after deposition of 4Di-10ASP into the PN graft. Large cell bodies with long, simply ramifying dendrites were always found ( $n=3$ retinas). Same numbers of randomly distributed cells were measured and pooled to obtain the histogram shown in $B$. The average size of the perikarya was 389 $\pm 120 \mu \mathrm{m}^{2}$; that is, larger than in earlier stages of examination (see Fig. 11). $C$ and $D$, Morphologies and soma size distribution of RGC in retinas with SC-reconnected grafts 6 months after surgery. Cells of the large types, but also many small cells, were present in the three retinas examined. In addition, the density of labeled neurons was much higher than in blind-ending grafts (see also Fig. $2 B$ ). The size distribution histogram in $D$ shows a range similar to that in $B$, but the average size of $303 \pm 101 \mu \mathrm{m}^{2}$ was smaller than in the blind-ending paradigm, although the difference was not significant at the $95 \%$ level of confidence. Scale bar, $100 \mu \mathrm{m}$. 

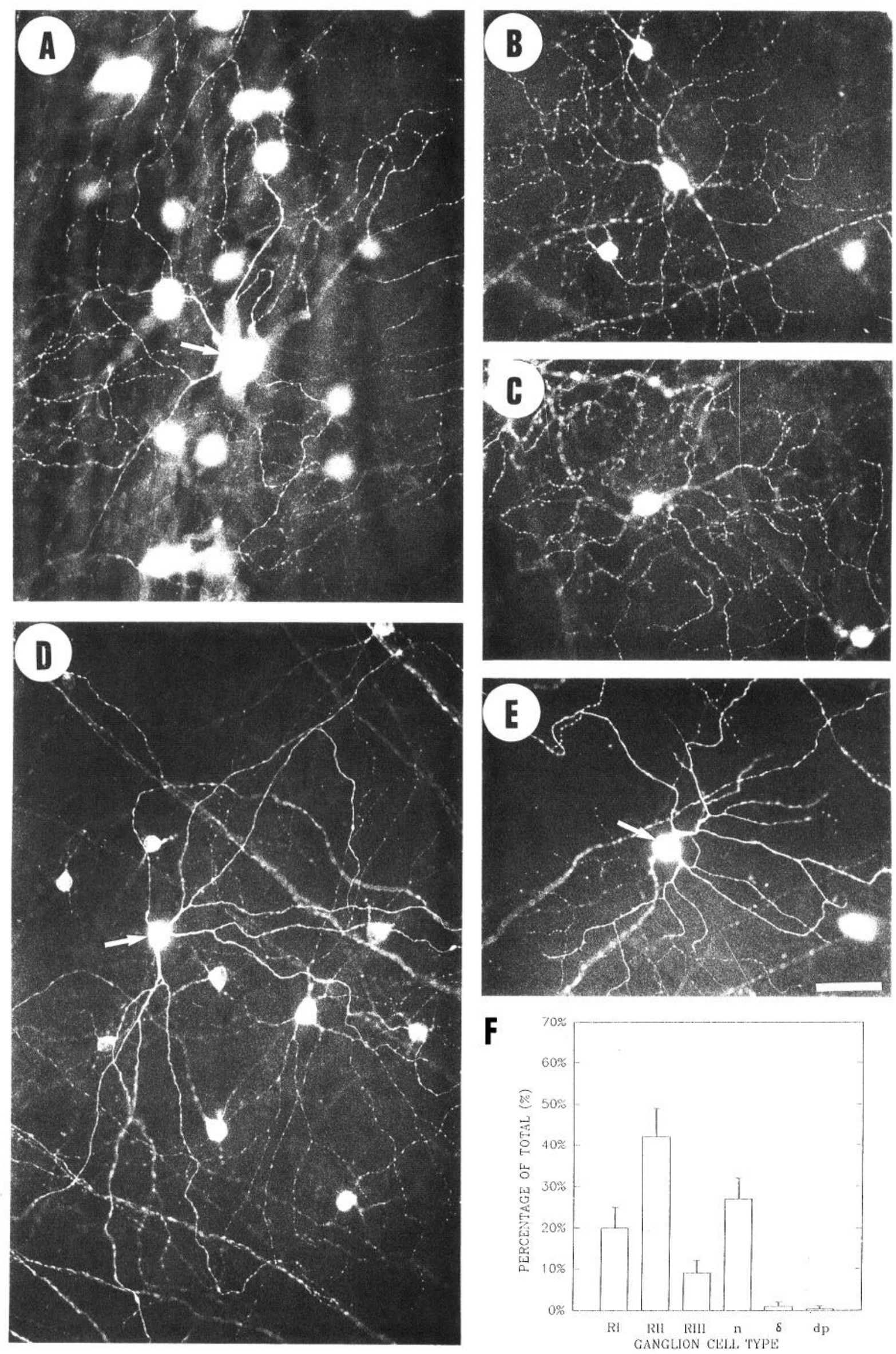
of the major types of ganglion cells within the normal rat retina display a type-specific and density-dependent overlap, as can be assessed by reduced silver impregnation (Peichl, 1989). The overlap is proportional to the cell density and to the dendritic field size and is defined as: coverage factor $=$ cell density $\times$ dendritic field area (Peichl, 1989). Cells with higher densities, like the type II cells, to which more than $70 \%$ of all ganglion cells belong, have therefore much higher coverage factors than type I cells (ca. $3-4 \%$ of the total population) or type III cells (also about $4 \%$ of the total). Peichl (1989) calculated in either reduced silver- or Lucifer yellow-filled normal type I ganglion cells the coverage factor to be 1.4 for the inner and 2.1 for the outer type I cells.

In the largely depopulated ganglion cell layer of regenerating retinas, between 10 and $20 \%$ of the remaining cells regrew axons which entered the SC or the pretectum. Reduction of cells affected all retinal quadrants and eccentricities. This resulted in uniform distribution of regenerating RGC over the retinal surface with a slightly higher density within the central retina (up to $1.5 \mathrm{~mm}$ from the optic nerve head, see also the higher central coverage factors in the three animals listed in Table 1). Given the fact that rcgencrating ganglion cells can transmit information to central neurons after resynaptogenesis (Carter et al., 1989; Keirstead et al., 1989), it is crucial to study whether this population is of any functional relevance for the operated animal or not. A major prerequisite for function is a retinotopic presentation of the ganglion cells within the regenerating nerve and on the surface of the central target. In turn, retinotopic presentation of the entire visual field can be achieved, if the total retinal surface is covered by ganglion cell dendrites. In practice, we estimated the coverage factors of the three major groups of regenerating ganglion cells by multiplying the average cell density with the average dendritic field area of each type of cell. Calculation of the coverage factor for type RI cells in the retinocollicular grafts revealed values ranging from 0.3 to 0.7 (Table 1); that is, lower than in the normal rat retina (Peichl, 1989). In retinopretectal grafts, the coverage factor of RI cells was higher (1.2-1.8), because of the higher density of these cells. Type RII cells, which numerically represent the most prominent subpopulation, displayed higher densities in the retinocollicular grafts and therefore higher degrees of overlapping, with coverage factors ranging from 8.1 to 13.6 (Table 1). In retinopretectal grafts with fewer cells of type RII, the coverage factors ranged from 0.5 to 0.8 and indicated their selective disappearance in favor of the larger cells. In terms of retinal occupation, the coverage factors determined for both groups of retinas imply that the regenerating retina had sufficient $\mathrm{RGC}$ for a simplified dendritic occupation. Type RIII cells, which are less numerous in the regenerating population, had coverage factors between 0.8 and 1.5 (Table 1) in both groups.

Figure 16 shows a retinal sector extending from the optic nerve head to the periphery in a retina with a mean cell density of $322 \mathrm{RGC} / \mathrm{mm}^{2}$ (i.e., $18 \%$ of the averaged normal RGC population) at the second month after grafting (Fig. 16 A). Classi-

\begin{tabular}{|c|c|c|c|c|c|c|}
\hline \multirow{2}{*}{$\begin{array}{l}\text { Cell density } \\
\left(\mathrm{RGC} / \mathrm{mm}^{2}\right)\end{array}$} & \multicolumn{3}{|c|}{ Cell type $\left(\mathrm{RGC} / \mathrm{mm}^{2}\right)$} & \multicolumn{3}{|c|}{ Coverage factor } \\
\hline & RI & RII & RIII & RI & RII & RIII \\
\hline SC 260 & 8 & 246 & 5 & 0.4 & 9.7 & 0.8 \\
\hline SC 218 & 6 & 207 & 5 & 0.4 & 8.1 & 0.8 \\
\hline SC 278 & 7 & 264 & 7 & 0.4 & 10.1 & 1.1 \\
\hline SC 322 & 9 & 304 & 9 & 0.5 & 11.9 & 1.4 \\
\hline $\mathrm{SC} 235^{a}$ & 8 & 222 & 5 & 0.4 & 8.7 & 0.8 \\
\hline $\mathrm{SC} 222^{a}$ & 6 & 211 & 5 & 0.3 & 8.2 & 0.8 \\
\hline $\mathrm{SC} 356^{\prime \prime}$ & 12 & 346 & 8 & 0.7 & 13.6 & 1.3 \\
\hline $\mathrm{SC} 312^{h}$ & 9 & 296 & 7 & 0.5 & 12.3 & 1.2 \\
\hline $\mathrm{SC} 354^{b}$ & 12 & 333 & 9 & 0.7 & 13.1 & 1.5 \\
\hline PT $124^{a}$ & 24 & 89 & 11 & 1.3 & 2.7 & 1.8 \\
\hline PT $186^{a}$ & 32 & 126 & 14 & 1.7 & 4.5 & 2.4 \\
\hline PT $140^{a}$ & 37 & 93 & 10 & 2.0 & 3.6 & 1.7 \\
\hline
\end{tabular}

In these animals the coverage factors were determined only in the central retina (optic nerve head to $1.5 \mathrm{~mm}$ of eccentricity) to show that the central retina has higher densities of RGC and therefore higher coverage factors.

"Coverage factor $=$ ganglion cell density $\times$ dendritic field area.

" These animals were analyzed 12 weeks after grafting.

fication of the RGC according to the criteria applied throughout this study and superimposition of the average dendritic field diameter of RI or RIII cells revealed that large areas of the retina were not occupied by these cells' dendrites (Fig. 16B,D). Type RII cells with higher factors of covcrage (Table 1) showed a clear overlap of dendritic territories (Fig. 16C).

\section{Discussion}

We used a combined model of neuroprotection and transplantation to assess the role of central targets in neuronal survival and type-specific morphological stabilization. The principal new findings of the present study are: (1) Influences on the retinal microglial activity at the time of optic nerve transection retarded ganglion cell degradation and prevented, to a substantial degree, the regressive alterations of the ganglion cell dendrites. (2) Combined treatment of the retina with microglia-inhibiting factor and transplantation of an autologous peripheral nerve piece permitted regeneration of axons from identifiable and morphometrically classifiable cells. (3) Initial morphologies and sizes of regenerating ganglion cells depended on the microglial inhibition and on the peripheral nerve environment. (4) Reconnection of the retina with the superior colliculus stabilized both the quantity of small regenerating neurons of type RII cells and their type-specific morphologies. (5) In contrast to the retinocollicular projection, reconnection of the retina with the pretectum resulted in selective survival and stabilization of large cells which belonged to type RI cells. (6) The numbers of regenerating ganglion cells sufficed to cover the retinal surface with dendrites, and at least the type RII cells in the retinocollicular and RI cells in the retinopretectal pathways displayed an

\footnotetext{
Figure 13. Morphological classification of regenerating RGC 24 weeks after grafting and reconnection of the retina with the ipsilateral SC. $A$, Cell of type RI (arrow). $B$ and $C$, Cells of type RII with small perikarya and thin, bushy dendrites. $D$, Cell of type RIII (arrow) surrounded by RII cells, whose dendrites ramify within a deeper sublayer of the IPL and therefore are out of focus. $E$, Unclassifiable RGC (arrow) with tortuous dendrites. Scale bar, $50 \mu \mathrm{m} . F$, Quantitative contribution of the various cell types to the total population of regenerating cells ( 1580 completely labeled RGC of three retinas). Type RI cells comprised $20 \%$, RII cells $42 \%$, RIII cells $9 \%$, unclassifiable cells $27 \%$, $\delta$-like cells $1 \%$, and displaced cells less than $1 \%$ of the population.
} 

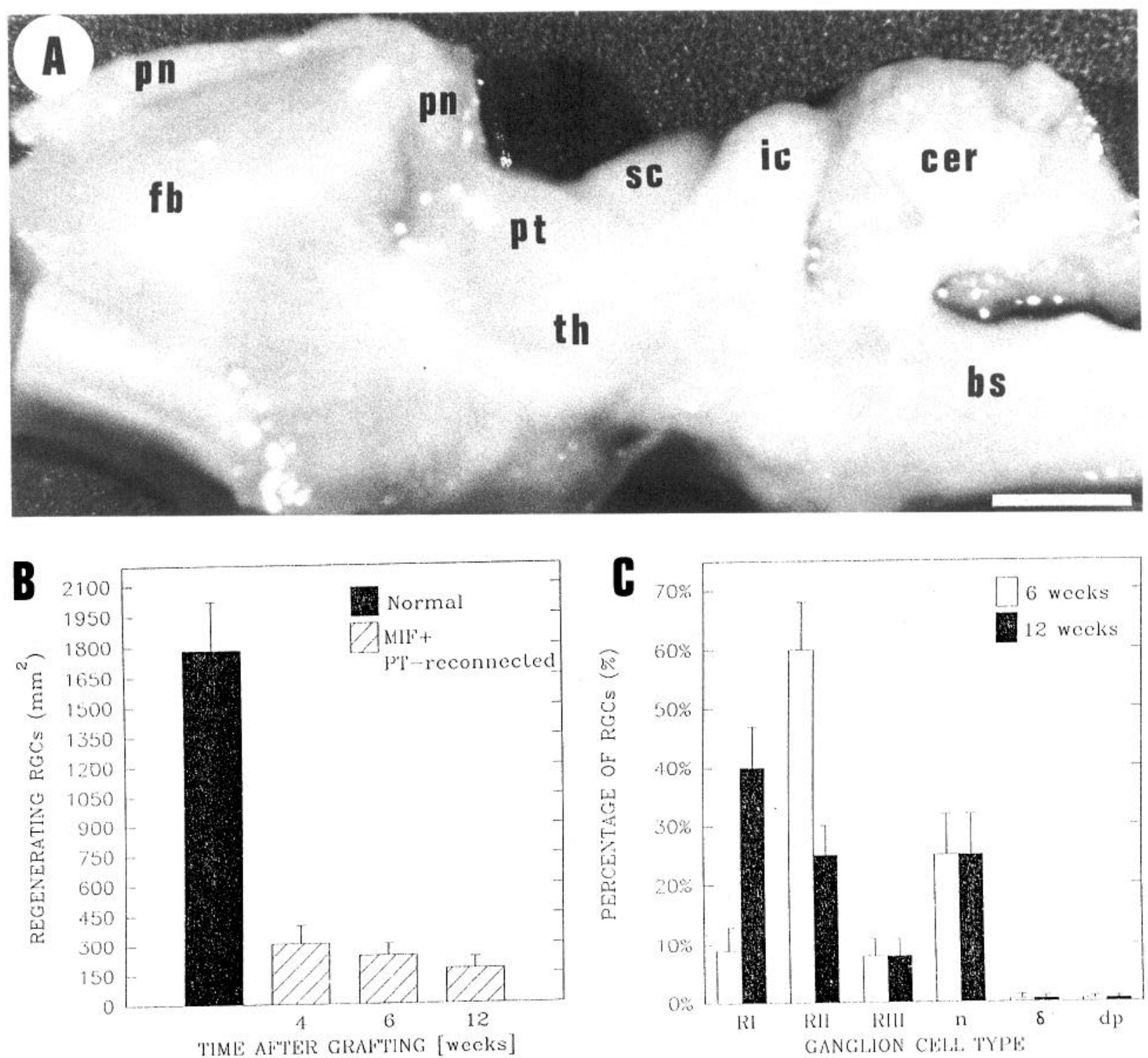

Figure 14. A, Left-lateral view of the half-brain of a rat 12 weeks after reconnection of the retina with the pretectum. bs, brain stem; cer, cerebellum; $f b$, forebrain; $i c$, inferior colliculus; $s c$, superior colliculus; $p n$, peripheral nerve graft; $p t$, pretectum; $t h$, thalamus. The retrogradely filled RGC of the same animal are shown in Figure $15, B$ and $C . B$, Densities of regenerating RGC in retinopretectal grafts compared to the normal population that could be labeled from the SC. The numbers represent average densities \pm SD from three retinas per time after surgery. $C$, Proportional contribution of the different RGC types to the total retrogradely labeled population at 6 and 12 weeks after surgery.

appreciable degree of coverage with potential functional significance for the retinofugal projection.

\section{The response of ganglion cells and microglia to axotomy}

Transection of the optic nerve in adulthood initiates a cascade of retrograde neuronal (Ramón y Cajal, 1932; James, 1933; Liebermann, 1971; Misantone et al., 1984; Barron et al., 1986) and environmental responses that culminate in the protracted disappearance of the retinal ganglion cells and their replacement with proliferating glial cells. These intraretinal responses are closely associated with the failure of transected mammalian axons to re-elongate. In contrast to this feature, amphibian and fish optic axons show extensive regrowth and successful reconnectivity (for review, see Grafstein, 1986). The sustained in-

Figure 15. A, Retrogradely filled RGC in a retinotectal graft 4 weeks after transplantation. Cells of the various sizes and types contributed to regeneration. The image does not differ from the other groups of grafts (compare with Figs. 8, 9). $B$, Same retinal region of an animal with retinopretectal graft and restored pupilloconstriction response (Thanos, 1992) 12 weeks after grafting. There are almost only large cells, reminiscent of type RI, and fewer small cells of type RII (arrows). C, Higher magnification of the cells shows their well preserved dendritic silhouettes which, together with the perikaryal images and sizes, permits grouping these cells into type RI. The cell indicated with the arrow belongs to type RII, whereas the cell indicated with an arrowhead ramifies within a deeper sublayer (out of focus) of the IPL and belongs to type RIII. Scale bars, 50 $\mu \mathrm{m}$ for $A$ and $B ; 25 \mu \mathrm{m}$ for $C$. 

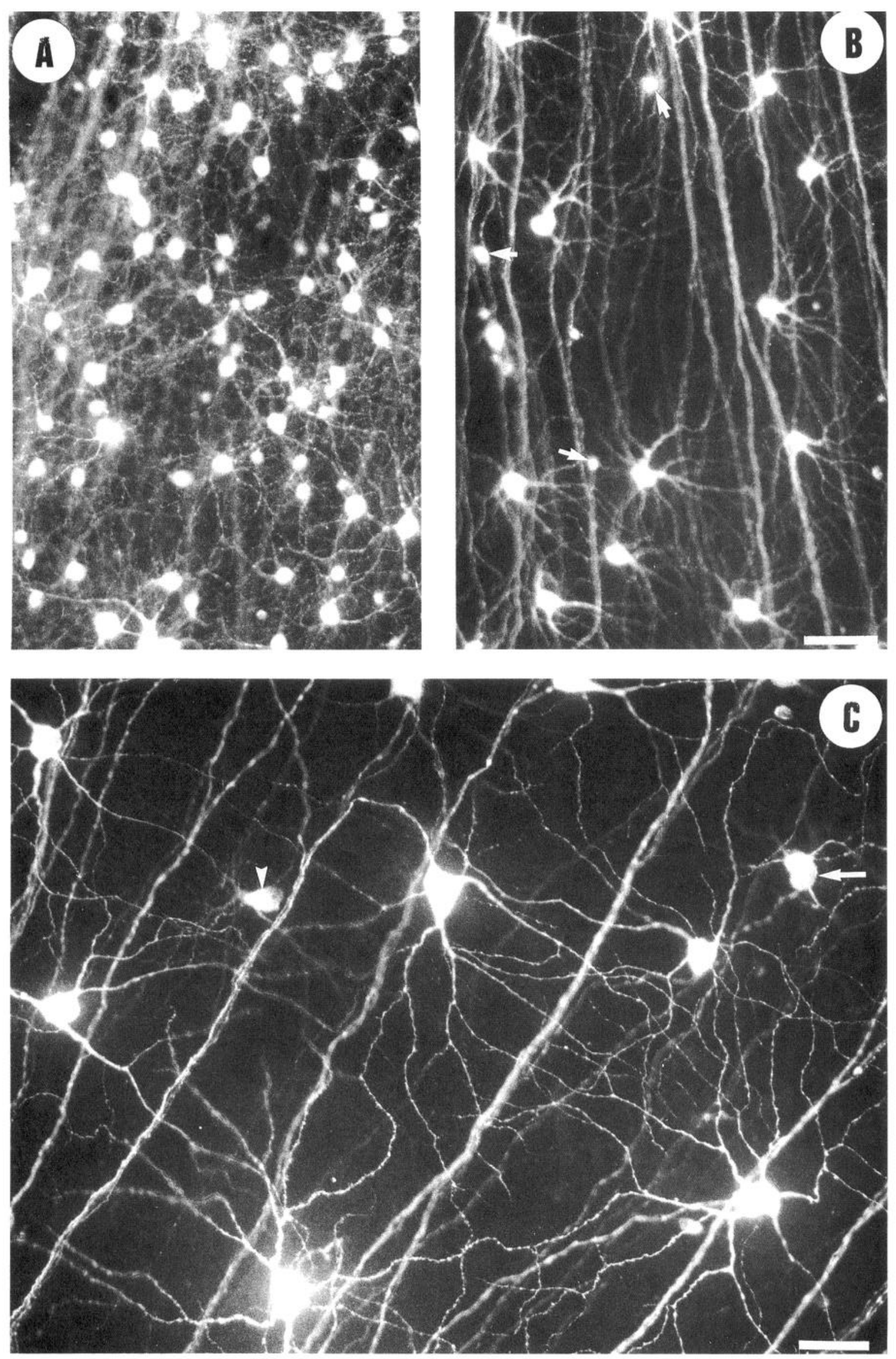


\section{DENDRITIC COVERAGE IN RECONNECTED RETINA}

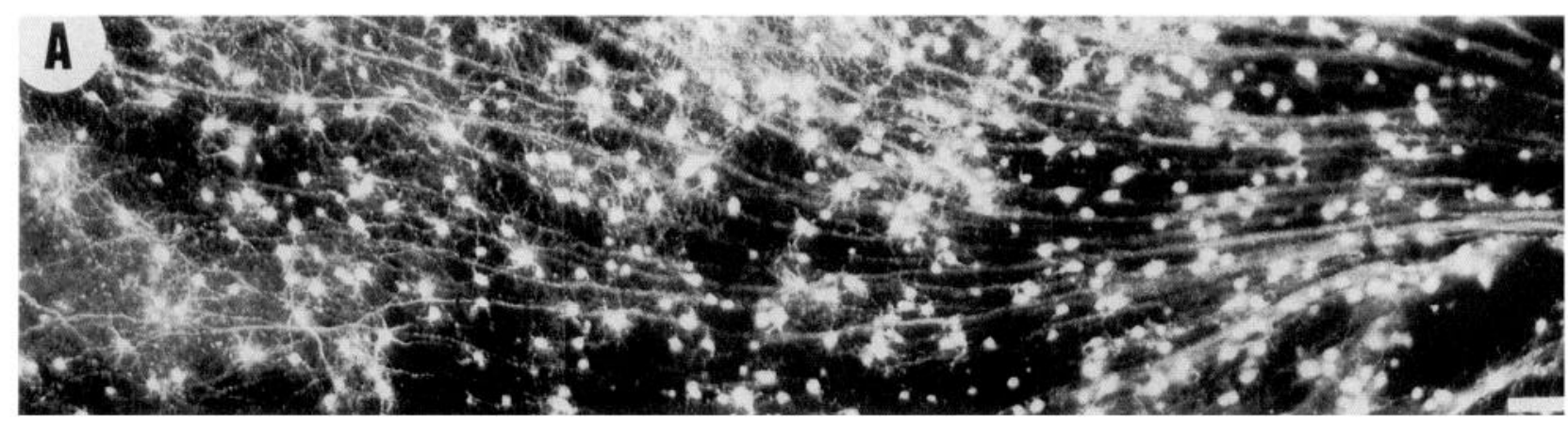

TYPE RI

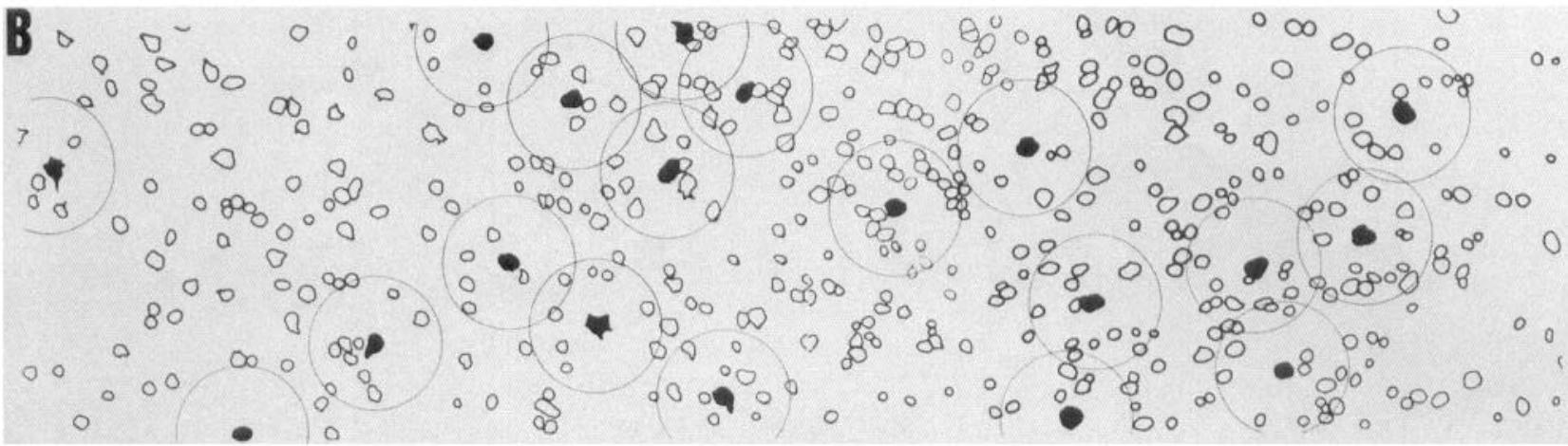

TYPE RII

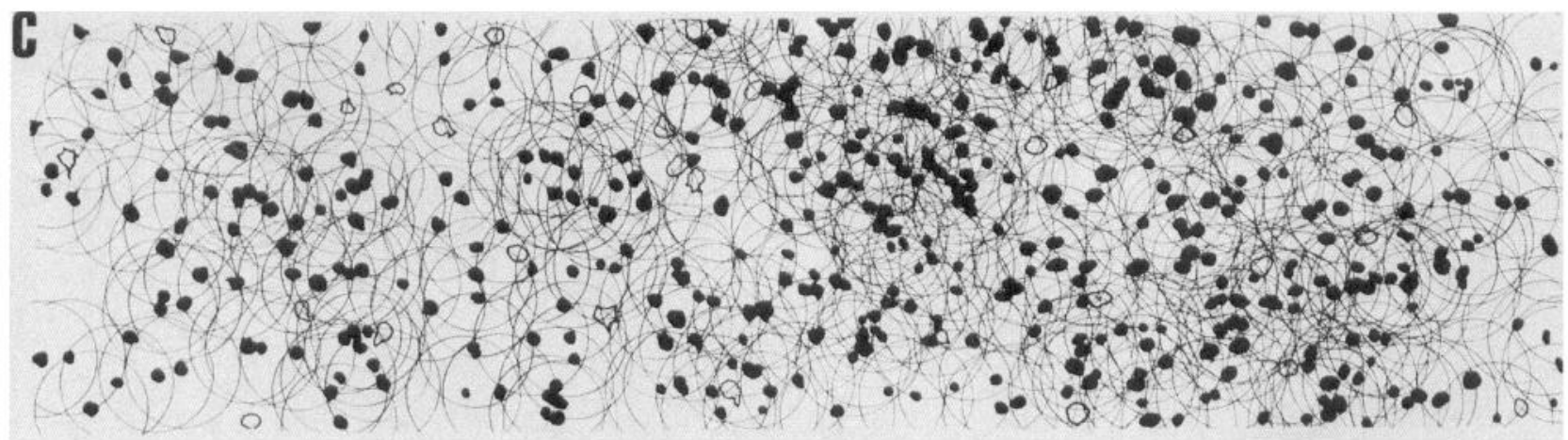

TYPE RIII

D

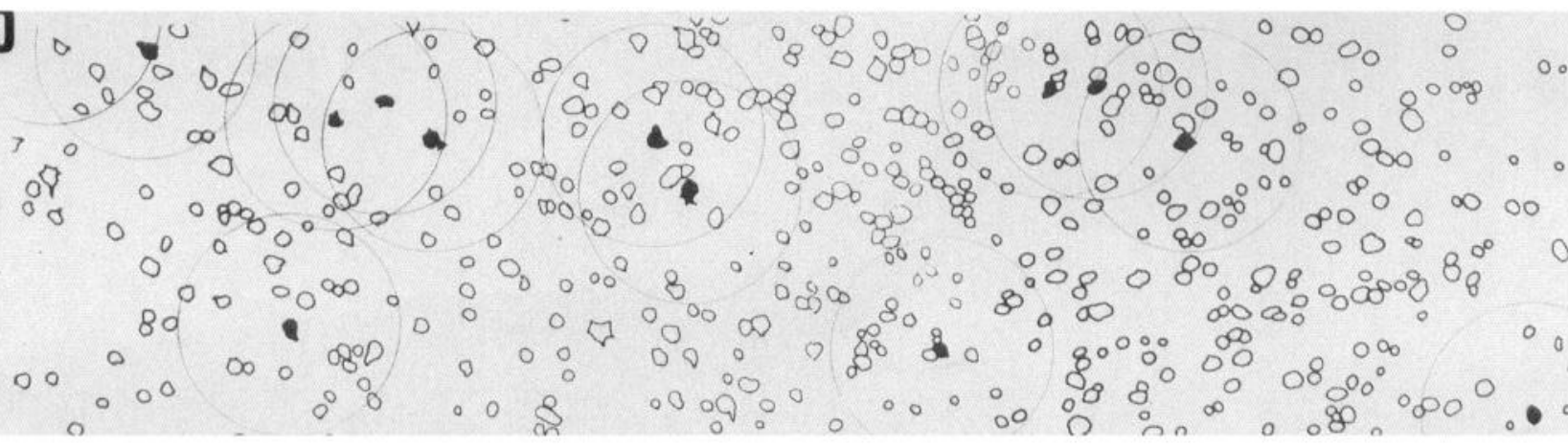


trinsic ability of some central mammalian neurons to regrow their axons into favorable environments such as transplanted peripheral nerve pieces has initially been considered as a paradoxic response (for review, see Aguayo, 1985). This consideration was flawed by an insufficient description of the inhibiting oligodendroglial influences on the severed cells (Schwab and Caroni, 1988) and of the neurotoxic effects of axotomy-inducible activation of intraretinal microglial cells (Thanos et al., 1993). The microglia-mediated degradation of the ganglion cells after axotomy (Thanos et al., 1993) can be circumvented to produce a higher incidence of survival and regeneration. Consequently, one of the strategies that yields enhanced numbers of neurons for axonal regrowth is to block the neurodestructive effects of microglial cells after axotomy, and to provide opportunities for axonal regrowth either in vivo (Vidal-Sanz et al., 1987) or in vitro (Thanos et al., 1993). The present study confirmed that this combined strategy is the most efficient toward retention of more regenerating neurons and protection of cellular degradation.

\section{Stabilization of classifiable regenerating ganglion cells}

The cells oblained after treatment with MIF and reconnection of the retina with central targets differed morphologically from the simplified cells observed after axotomy alone and from those whose axons grew into a nonreconnected PN graft without MIF treatment (Thanos, 1988b; Thanos and Aguayo, 1988; Lau et al., 1991). This difference was likely due to the protective effect of the microglial inhibition at the early phase of the ganglion cell response, which affects a large proportion of axotomized neurons, also called rapid response (Villegas-Perez et al., 1993). Lau et al. (1991) confirmed these findings with intracellular Lucifer yellow injections and concluded that the opportunity of neurons to regenerate an axon is not closely related to the dendritic responses and the PN graft, and grafting alone does not seem to be able to prevent the deterioration and retraction of dendritic branches (Lau et al., 1991). A certain degree of dendritic retraction was also obtained in the present study, although the regressive changes were less pronounced and permitted identification and classification of most of the regenerating ganglion cells. This indicated that either the blockade of the microglial cells was incomplete, or that additional, not yet identified mechanisms contributed to the retraction of the dendritic arbors. As an example, such dendritic changes may be also codetermined by shedding of the synaptic input to the fine dendritic arbors of higher order (Mendell, 1984). In spite of neuroprotection, about $25 \%$ of the $\mathrm{RGC}$ remained unclassifiable, due to dendritic alterations, which frequently effect terminal and preterminal branches (Thanos and Aguayo, 1988). Most of the unclassifiable cells had small to medium sizes of perikarya and most likely belonged to the type RII cells with similar cell bodies. Since the present classification was based on both perikaryal and dendritic silhouettes, we preferred to group them separately, because of the inability to identify dendritic regularities.

We can generally distinguish between two phases of axonal regeneration: The first stage is initiated by formation of growth cones at the site of anastomosis between the optic nerve stump and the PN graft, which was dated to the sixth day (Trecarten et al., 1987) and extends up to the fourth to fifth week after grafting (Vidal-Sanz et al., 1987; Thanos, 1992). Schwann cells within the grafted piece of the peripheral nerve proliferate 2-3 d after surgery (Aguayo, 1985) and enable the formation of growth cones at the cut stumps of axons (Trecarten et al., 1987). As expected, a "conditioning" crush of the PN 1 week before grafting did not influcnce the efficiency of axonal regrowth. The reported enhancement of surviving neuronal populations (Bähr et al., 1992) may have been caused by the method used to detect ganglion cells. These authors used the method of prelabeling ganglion cells with the fluorescent carbocyanine dye DiI, which after axotomy is taken up by phagocytosing microglial cells (Thanos, 1991). Due to this "contamination" of the fluorescent cell population, Bähr and colleagues may have considered some of the labeled microglial cells as neurons, and included them in their measurements (M. Bähr, personal communication).

The second stage of regeneration starts by the time of fiber ingrowth into the central areas and covers the phase of resynaptogenesis within these targets. The morphologies of ganglion cells during the first phase seem to be target independent and to depend only on pharmacological treatment of the retina with MIF (Thanos et al., 1993) or on neurotrophic agents derived from the PN graft (Villegas-Perez et al., 1988; Thanos et al., 1989). Some of these factors which had been isolated and injected into the vitreous body resulted in retardation of $\mathrm{RGC}$ decay (Sievers et al., 1987; Carmignoto et al., 1989; Mey and Thanos, 1993). Since transition from the first to the second phase was experimentally prevented in the group of blind-ending grafts, all changes that took place in these three experimental groups during the second phase were probably due to different mechanisms. In blind-ending grafts, protracted cell death caused a continuous reduction of ganglion cell numbers and at the same time survival of larger ganglion cells, which remained vital until 24 weeks after grafting, and perhaps much longer (Thanos and Mey, unpublished observations). Given that all the different cell types regrew their axons into the grafted PN pieces, and assuming that the indigenous graft environment influenced the survival of all axotomized neurons equally well (Villegas-Perez et al., 1988), we discovered that the experimental parameter "target" exerted additional selective influences on subsets of neurons. Ingrowth of axons either into the $\mathrm{SC}$ or pretectum created

Figure 16. Dendritic coverage of the retinal surface. $A$, A sector of a reconnected retina 8 weeks after grafting shows a dense appearance of fluorescent RGC whose axons had regenerated and were retrogradely labeled with 4Di-10ASP from the graft. Scale bar, $100 \mu \mathrm{m} . B$, Presentation of the same retinal sector with the type RI cells identified at higher microscopic magnification and indicated as black-filled cells in the ink drawing. Cells of types RII and RIII are indicated as unfilled circles in this drawing. The average size of the dendritic field for this cell type (mean: 0.055 $\mathrm{mm}^{2}$ ) is represented as a circle and is overlaid to each one of the cells belonging to the RI class. As the figure shows, the RI cell density does not suffice to cover the retinal sector with dendrites (see also Table 1 for quantification). $C$, Cell somata of type RII and unclassifiable cells in the same retinal sector as shown in $A$ are marked with black ink. Because unclassifiable RGC have dendritic sizes similar to type RII cells, they were pooled for reasons of convenience with RII cells in this coverage factor calculation. These cells have higher density and suffice to cover the retinal scetor completely. The obvious dense overlap and the coverage factors calculated from the dendritic fields (mean: $0.039 \mathrm{~mm}^{2}$ ) for this type of cell (see Table 1) show that there are substantially more cells than needed to simply cover the retinal surface. $D$, Presentation as before, here for cells of type RIII. As shown for the cells of type RI, RIII cells, which have density similar to RI cells, are not frequent enough to cover the retina, although their dendritic fields are larger (mean: $0.167 \mathrm{~mm}^{2}$ ). 
contacts of these axons with target cells, and perhaps with glial cells (Engele and Bohn, 1991) within the target areas. These contacts seem to enhance the chance of smaller cells to survive selectively in dependence of the SC, whereas larger or type RI cells with morphologies reminiscent of type I neurons projecting to thalamic relay nuclei (for review, see Sefton and Dreher, 1985) were predominantly supported when the axons approached the pretectum. Moreover, both targets stabilized the morphological silhouettes of the cells and permitted their identification and classification. Although the survival of cells cannot be directly attributed to synaptic contacts being reestablished in the regenerating retinofugal system (Vidal-Sanz et al., 1987; Carter et al., 1989; Keirstead et al., 1989), the selective survival of different cells in the two reconnection groups speaks in favor of a resynaptogenesis-dependent stabilization. Evidence for this interpretation is based on the fact that in the retinopretectal paradigm, synaptic contacts are formed in sufficient number and with appropriate specificity to restore the light-inducible pupilloconstriction reflex (Thanos, 1992). On the other hand, the fact that retinocollicular synaptic profiles did not differ morphologically from those in normal hamsters (Carter et al., 1989) speaks also in favor of the synaptogenesis-dependent stabilization of $\mathrm{RGC}$ after regeneration. In addition, is it ruled out that extracellular matrix molecules like laminin or brain-derived growth factors like BDNF (Barde, 1989) play a role in stabilization of reconnected cells, as they do in the developing retinofugal system (Rodriguez-'Tébar et al., 1989; Hankin and Lund, 1991). This seems less likely in the regenerating system, since pretectum and SC sclectively rescue different subsets of neurons as expected from synaptogenesis-dependent (Murray et al., 1986) rather than from neurotrophic influences.

An accurate classification of ganglion cells would include both morphological and physiological characterization, as has been done for the normal RGC (Fukuda, 1977; Perry, 1979). The well established, consistent morphologies of RGC correlating with cerlain physiological properties (Fukuda, 1977) permit, however, categorizing ganglion cells exclusively on the basis of their morphologies. It became, indeed, apparent during the experiments that the categories termed RI, RII, RIII, R- $\delta$, and displaced cells may be considered as correlates of the normal ganglion cell types. It was also revealed that the compositions of the regenerating RGC were initially similar to those in the normal retina, to be later modified depending on the conditions of whether the axons were allowed to enter and innervate central targets or not. These findings are best reconciled with the view that the different types of neurons possess, in principle, similar potential to regrow their axons, once exposed to the same experimental conditions.

\section{Does the number of regenerating ganglion cells suffice to restore function?}

In spite of neuroprotection and accessibility of a PN graft, most of the RGC degenerate after axotomy. However, the contribution of different types of $\mathrm{RGC}$ to the regenerating population and the coverage of the retinal surface may be seen as the first encouraging evidence to consider this population as functionally relevant. At least in one of the projections examined in this paper, the retinopretectal system, about $8.25 \%$ of RGC were sufficient to drive the pupillary constriction response (Thanos, 1992). In Xenopus, an animal with spontaneous ability for axonal regeneration, only $28 \%$ of axons regrow after crush, but they suffice to restore function of the retinotectal system, and the RGC then retain almost normal receptive fields (Stelzner and Strauss, 1986). A meaningful reconnection with the rat SC requires, in addition to the number of axons which approach central targets, a retinotopic pattern of reinnervation and formation of synaptic contacts with proper neurons to subserve visual function. We have at least succeeded in showing that the major classes of regenerated ganglion cells form mosaics with type-specific coverage properties, which would serve to prevent large scotomas. In the normal retina (Wässle and Riemann, 1978; Wässle et al., 1981; Peichl, 1989), a mosaic-like distribution of various categories of $\mathrm{RGC}$ is essential for the various functions of the visual system. The major difference between the regenerated and the normal retina consists in the number of cells, dramatically reduced after axotomy, and in morphological simplification, which is likely accompanied by a reduction of synaptic contacts within the IPL (Mendell, 1984), influencing the physiological properties of these cells. In the normal retina, $\alpha$ cells have a coverage factor of six to seven (Peichl, 1989). In the retinocollicular grafting paradigm, the RI cells have a coverage factor of less than one, indicating that the RI cell pattern does not suffice to dendritically cover the entire retinal surface. RI-like cells were, however, the predominant population in the retinopretectal paradigm, and displayed higher degrees of coverage. Similar to the RI neurons, RIII cells displayed coverage factors around one in both paradigms, with the large dendritic territories of neighboring cells overlapping partially but not to the extent that would assure complete retinal coverage. Coverage factors around 10 in the retinocollicular and around five to six in the retinopretectal system indicatc a higher degree of territorial overlap, as can also be discerned just by observing labeled retinas like the one shown in Figure 15, $B$ and $C$. There are no comparable studies on the coverage factors for the type III and II cells in the normal retina. This is apparently due to the fact that type III cells are incompletely described yet, and the high density of type II cells prevents a detailed analysis of coverage. However, given that the reduction of type II cells is quantitatively similar to that of type I cells, as we can assume from the present findings, one expects coverage factors higher than 50-60 in the normal retina. However, irrespective of whether the regenerating population will approach the normal one, the retinal surface of the experimental animals is lacking large, RGC-less gaps that would cause visual field defects (=scotomas). This functional consideration poses a challenge to analyze the other prerequisites for functional regeneration; that is, the retinotopy of the created retinofugal pathway and the quantity and specificity of synapses (both objects of ongoing studies) within the colliculus in order to establish whether restoration of some degree of vision is possible or not.

\section{References}

Aguayo AJ (1985) Axonal regeneration from injured neurons in the adult mammalian central nervous system. In: Synaptic plasticity (Cotman CW, ed), pp 457-484. New York: Guilford.

Auriault C, Joseph M, Tartar A, Capron A (1983) Characterization and synthesis of a macrophage inhibitory peptide from the second constant domain of human immunoglobulin G. FEBS Lett 153:1115.

Bähr M, Eschweiler GW, Wolburg H (1992) Precrushed sciatic nerve grafts enhance the survival and axonal regrowth of retinal ganglion cells in adult rats. Exp Neurol 116:13-22.

Barde YA (1989) Trophic factors and neuronal survival. Neuron 2:1525-1534.

Barron KD, Dentinger MP, Lohel G, Easton SK, Mankes R (1986) Qualitative and ultrastructural observations on retinal ganglion cell layer of rat after intraorbital nerve crush. J Neurocytol 15:345-362. 
Berry M, Ries L, Sievers J (1986) Unequivocal regeneration of rat optic nerve axons into sciatic nerve isografts. In: Neural transplantation and regeneration (Das GD, Wallace RB, eds), pp 63-79. New York: Springer.

Carmignoto G, Maffei L, Candeo P, Canella R, Comelli C (1989) Effect of NGF on the survival of rat retinal ganglion cells following optic nerve section. $J$ Neurosci 9:1263-1272.

Carter D, Bray GM, Aguayo AJ (1989) Regenerated ganglion cell axons can form well-differentiated synapses in the superior colliculus of adult hamsters. J Neurosci 9:4042-4050.

Clarke RJ, Ikeda H (1985) Luminance and darkness detectors in the olivary and posterior pretectal nuclei and their relationship to the pupillary light reflex in the rat. Exp Brain Res 57:224-232.

del Rio-Hortega P (1932) Microglia. In: Cytology and cellular pathology of the nervous system (Penfield $W$, ed), pp 482-534. New York: Hoeber.

Dreher B, Sefton AJ, Ni SYK, Nisbett G (1985) The morphology, number, distribution and cen tral projections of class I retinal ganglion cells in albino and hooded rats. Brain Behav Evol 26:10-48.

Engele J, Bohn MC (1991) The neurotrophic effects of fibroblast growth factors on dopaminergic neurons in vitro are mediated by mesencephalic glia. J Neurosci 11:3070-3078.

Fukuda Y (1977) A three-group classification of retinal ganglion cells: histological and physiological studies. Brain Res 119:327-344.

Giulian D, Chen J, Ingeman JE, George JK, Noponen M (1989) The role of mononuclear phagocytes in wound-healing after traumatic injury to adult mammalian brain. J Neurosci 9:4416-4429.

Grafstein B (1986) Regeneration in ganglion cells. In: The retina, pp 275-335. Orlando, FL: Academic.

Hankin M, Lund RD (1991) How do retinal axons find their targets in the developing brain? Trends Neurosci 14:224-228.

Hulthorn H, Mori K, Tsukahara N (1978) The neuronal pathway subserving the pupillary light reflex. Brain Res 159:255-267.

James GR (1933) Degeneration of ganglion cell following axonal injury. Arch Ophthalmol 9:338-343.

Keirstead SA, Rasminsky M, Fukuda Y, Carter DA, Aguayo AJ, VidalSanz M (1989) Electrophysiological responses in hamster superior colliculus evoked by regenerating retinal axons. Science 246:255-257.

Klassen H, Lund RD (1990) Retinal graft-mediated pupillary responses in rats: restoration of a reflex function in the mature mammalian brain. J Neurosci 10:578-587.

Lau KC, So K-F, Cho EYP (1991) Morphological changes of retinal ganglion cells regenerating axons along peripheral nerve grafts: a Lucifer Yellow and silver staining study. Restor Neurol Neurosci 3:235246.

Lieberman AR (1971) The axon reaction: a review of the principal features of perikaryal responses to axon injury. Int Rev Neurobiol $14: 49-124$.

Linden R, Perry VH (1983) Massive retinotectal projection in rats. Brain Res 272:145-149.

Mendell LM (1984) Modifiability of spinal synapses. Physiol Rev 64: 260-323.

Mey J, Thanos S (1993) Intravitreal injections of neurotrophic factors support the survival of axotomized retinal ganglion cells in adult rats in vivo. Brain Res 602:304-317.

Misantone LJ, Gerschenbaum M, Murray M (1984) Viability of retinal ganglion cells after optic nerve crush in adult rats. J Neurocytol 13: 449-465.

Murray MS, Sharma S, Edwards MA (1982) Target regulation of synaptic number in the compressed retinotectal projection of the goldfish. J Comp Neurol 209:374-385.

Peichl L (1989) Alpha and delta ganglion cells in the rat retina. J Comp Neurol 286:120-139.

Perry VH (1979) The ganglion cell layer in the retina of the rat. Proc R Soc Lond [Biol] 204:363-375.

Perry VH, Gordon S (1988) Macrophages and microglia in the nervous system. Trends Neurosci 11:273-277.

Plata-Salaman CR (1989) Immunoregulators in the nervous system. Neurosci Biobehav Rev 15:185-215.

Politis MJ, Spencer PS (1986) Regeneration of rat optic axons into peripheral nerve grafts. Exp Neurol 91:52-59.

Ramón y Cajal S (1928) Degeneration and regeneration of the nervous system (May RM, trans). London: University Press.
Rodríguez-Tébar A, Jeffrey PL, Thoenen H, Barde YA (1989) The survival of chick retinal ganglion cells in response to brain-derived neurotrophic factor depends on their embryonic age. Dev Biol 136: 296-303.

Schober W, Gruschka H (1977) Die Ganglienzellen der Retina der Albinoratte: eine qualitative und quantitative Studie. Z Mikrosk Anat Forsch 91:397-414.

Schwab ME, Caroni P (1988) Oligodendrocytes and CNS myelin are non-permissive for neurite growth and fibroblast spreading in vitro. J Neurosci 8:2381-2393.

Sefton AJ, Dreher B (1985) Visual system. In: The rat nervous system, Vol 1 (Paxinos G, ed), pp 169-221. Sydney: Academic.

Sievers J, Hausmann B, Unsicker K, Berry M (1987) Fibroblast growth factors promote survival of adult rat retinal ganglion cells after transection of the optic nerve. Neurosci Lett 76:157-162.

So K-W, Aguayo AJ (1985) Lengthy regrowth of cut axons from ganglion cells after peripheral nerve transplantation into the retina of adult rats. Brain Res 328:439-454.

Stelzner DJ, Strauss JA (1986) A quantitative analysis of frog optic nerve regeneration: is retrograde ganglion cell death or collateral loss related to selective re-innervation? J Comp Neurol 245:83-106.

Thanos S (1988a) Morphology of ganglion cell dendrites in the albino rat retina: an analysis with fluorescent carbocyanine dyes. J Hirnforsch 29:617-631.

Thanos S (1988b) Alterations in the morphology of ganglion cell dendrites in the adult rat retina after optic nerve transection and grafting of peripheral nerve segments. Cell Tissue Res 259:599-609.

Thanos S (1991) The relationship of microglial cells to dying neurons during natural neuronal cell death and axotomy-induced degeneration. Eur J Neurosci 3:1189-107.

Thanos S (1992) Adult retinofugal axons regenerating through peripheral nerve grafts can restore the light-induced pupilloconstriction reflex. Eur J Neurosci 4:691-699.

Thanos S, Aguayo AJ (1988) Changes in dendrites of adult rat ganglion cells regenerating axons into peripheral grafts. In: Post-lesion neural plasticity (Flohr H, ed), pp 129-138. Berlin, Heidelberg: Springer.

Thanos S, Bähr M, Barde YA, Vanselow J (1989) Survival and axonal elongation of adult rat retinal ganglion cells. In vitro effects of lesioned sciatic nerve and brain derived-neurotrophic factor. Eur $\mathbf{J}$ Neurosci 1:19-26.

Thanos S, Mey J, Wild M (1993) Treatment of the adult retina with microglia-suppressing factors retards axotomy-induced neuronal degradation and enhances axonal regeneration in vivo and in vitro. $\mathrm{J}$ Neurosci 13:455-466.

Trecarten MJ, Villegas-Perez MP, Vidal-Sanz M, Thanos S, Aguayo AJ (1987) Growth of retinal axons along peripheral nerve system grafts inserted into the retina of adult rats. Soc Neurosci Abstr 12:701.

Trejo LJ, Cicerone CM (1984) Cells of the pretectal olivary nucleus are in the pathway of direct light reflex of the pupil in the rat. Brain Res 300:49-62.

Vanselow J, Schwab ME, Thanos S (1990) Responses of regenerating rat retinal ganglion cell axons to contacts with central nervous myelin in vitro. Eur J Neurosci 2:121-125.

Vidal-Sanz M, Bray GM, Villegas-Perez MP, Thanos S, Aguayo AJ (1987) Axonal regeneration and synapse formation in the superior colliculus by retinal ganglion cells in the adult rat. J Neurosci 7:2894 2909.

Vidal-Sanz M, Bray GM, Aguayo AJ (1991) Regenerated synapses persist in the superior colliculus after regrowth of retinal ganglion cell axons. J Neurocytol 20:940-952.

Villegas-Pérez MP, Vidal-Sanz M, Bray GM, Aguayo AJ (1988) Influences of peripheral nerve grafts on the survival and regrowth of axotomized retinal ganglion cells in adult rats. J Neurosci 8:265-280.

Villegas-Pérez MP, Vidal-Sanz M, Rasminsky M, Bray GM, Aguayo AJ (1993) Rapid and protracted phases of retinal ganglion cell loss follow axotomy in the optic nerve of adult rats. J Neurobiol 24:2336.

Wässle H, Riemann HJ (1978) The mosaic of nerve cells in the mammalian retina. Proc R Soc Lond [Biol] 200:441-461.

Wässle H, Peichl L, Boycott BB (1981) Dendritic territories of cat retinal ganglion cells. Proc R Soc Lond [Biol] 203:269-291. 